\title{
Přehrady a vodní bezobratlí živočichové
}

\section{DENISA NĚMEJCOVÁ, SVĚTLANA ZAHRÁDKOVÁ, MAREK POLÁŠEK}

Klíčová slova: makrozoobentos - jižní Morava - vodní nádrže - napřímení toků - vodní hospodářství - prírodní dědictví

\section{SOUHRN}

Budování vodních nádrží (přehrad) zásadně mění prírodu a krajinu nejen na zaplaveném území, ale i mimo něj, včetně všech struktur a vazeb. V rámci řešení projektu Ministerstva kultury ČR Zatopené kulturní a přírodní dědictví jižní Moravy (DF13P01OVV012) byla věnována pozornost třem jihomoravským lokalitám - Vranovské přehradě, Brněnské přehradě a vodnímu dílu Nové Mlýny. Na územích ovlivněných výstavbou přehrad se vyskytovaly specifické akvatické biotopy, vázané na vodní režim krajiny. Ty na zaplaveném území zanikly, nicméně některé typy existuji i v současnosti v blízkém či širším okolí nádrží. Se změnami v biotopech logicky docházelo ke změnám ve struktuře akvatických biocenóz.

Cílem studie bylo dokumentovat dopad vybudování vodních nádrží na různé typy vodních biotopů a na bezobratlé živočichy. Výsledkem je přehled strategií a modelových reakcí vodních bezobratlých na takto vyvolanou změnu jejich životního prostředí.

Z analýz vyplynulo, že nejvíce postiženým typem vodních biotopů jsou nížinné říční biotopy a na ně vázaná fauna. Druhy jepic Ephemerella mesoleuca a Isonychia ignota, které na území dnešního VD Nové Mlýny tvořily jednu z posledních populací v ČR, se zánikem vhodných biotopů na území ČR vyhynuly úplně. Jepice podeňka (Ephoron virgo), říční druh, podle červeného seznamu kriticky ohrožený, má ve sledovaných oblastech jednu z posledních lokalit v ČR. Mezi velmi postižené biotopy patří také vysychající (periodické) tůně a jejich obyvatelé, většinou korýši.

\section{ÚVOD}

Trvalým zaplavením určitého většího území se zcela nevratně změní nejen řeka a vodní biotopy v prílehlém inundačním území, ale i krajina, včetně všech struktur a vazeb. Změní se typy biotopů a současně s tím také jejich obyvatelé. Stavba údolních nádrží vytváří v prírodě zcela nové životní prostředí, které je dílem člověka a je jím i nadále ovlivňováno [1].

Vodní druhy rostlin i živočichů si dlouhodobě vyvíjely životní strategie $\checkmark$ prímé vazbě na prírozené režimy toků. Jakákoliv úprava či změna těchto režimů nutně vede $\mathrm{k}$ celé kaskádě změn v druhovém složení rostlin a živočichů $\checkmark$ dané oblasti. Jednou z nejzásadnějších změn projde řeka tehdy, vytvoříli člověk na jejím toku vodní nádrž. Vodní nádrže zpưsobují rozsáhlou změnu řady fyzikálních, chemických i biologických faktorů, které zapříčiňují změny v oživení toku [2]. Po výstavbě vodního díla je ovlivněn nejen samotný zaplavený úsek toku nad hrází, ale i poměrně dlouhý úsek toku pod hrází. Mění se i průtokový režim v řece pod prehradou, nejznatelnější jsou změny průtoku způsobené tzv. špičkováním vodních elektráren, tedy střídáním vysokých a nízkých průtoků v závislosti na provozu turbín, a to i několikrát denně. Dále zde dochází k teplotním změnám a ke změnám v plaveninovém režimu, protože

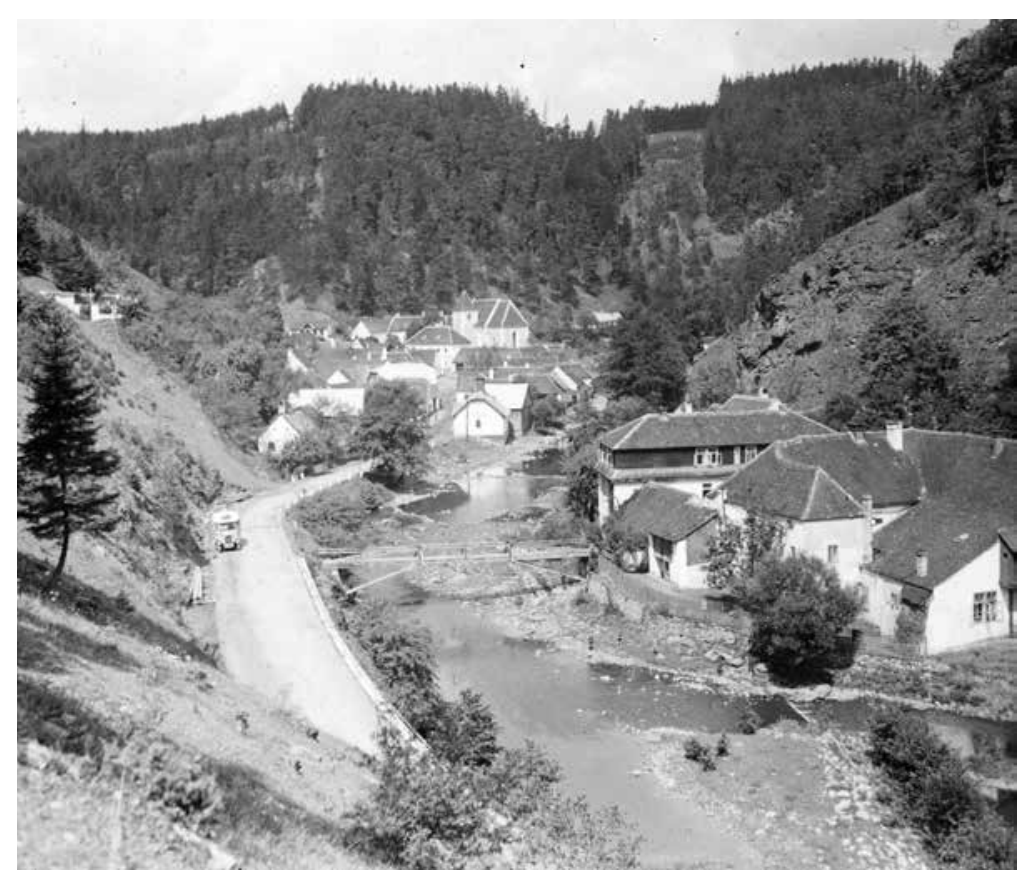

Obr. 1. Kaňonovité koryto řeky Dyje ve starém Bítově

Fig. 1. The Dyje River and its deep-cut meandering canyon in former Bítov village

prehrady fungují jako lapače sedimentovaných částic organického i anorganického původu. Výstavba hráze také přeruší říční kontinuum, a coby migrační překážka způsobí izolaci jednotlivých populací ríčních druhů živočichů i prerušení vazeb a následně zapř́činí změny v druhovém složení vodních společenstev.

Vazby vodních organismů $k$ podmínkám prostředí jsou poměrně dobře vymezené a známé. Každý druh má určitý soubor vlastností a také nároků na prostředí. Některé z vlastností umožňují přežívání i ve zdánlivě nepřijatelných podmínkách, některé z nároků naopak neumožňují přežít i v podmínkách jen o trochu jiných, než jsou ty specifické. Toho se využívá pro biologickou indikaci, kdy vlastně zpětně z výskytu určitých druhů usuzujeme na stav prostředí, a to zejména tehdy, když působí celý komplex vlivů, které se navzájem různě posilují anebo oslabují. Podle toho, zda se určité citlivé nebo specifické druhy (tzv. specialisté) někde vyskytují, můžeme poznat, zda je prostředí - biotop - ve vyhovujícím stavu. A také naopak, pokud jsou takové druhy nahrazeny druhy odolnými nespecializovanými (tzv. generalisté), je to známka degradace. Hodnocení podle výskytu organismů je důležité, protože ukazuje skutečnou funkci prírodních procesů $v$ daném biotopu. Zánik určitých typů biotopů nebo podstatné přerušení prirozených vazeb mezi nimi vede k narušení společenstev a funkcí ekosystémů. Navenek se tyto poruchy projevují většinou zhoršením kvality vody i výskytem nepůvodních a také invazních druhů, které stabilitu prostředí dále narušují. 


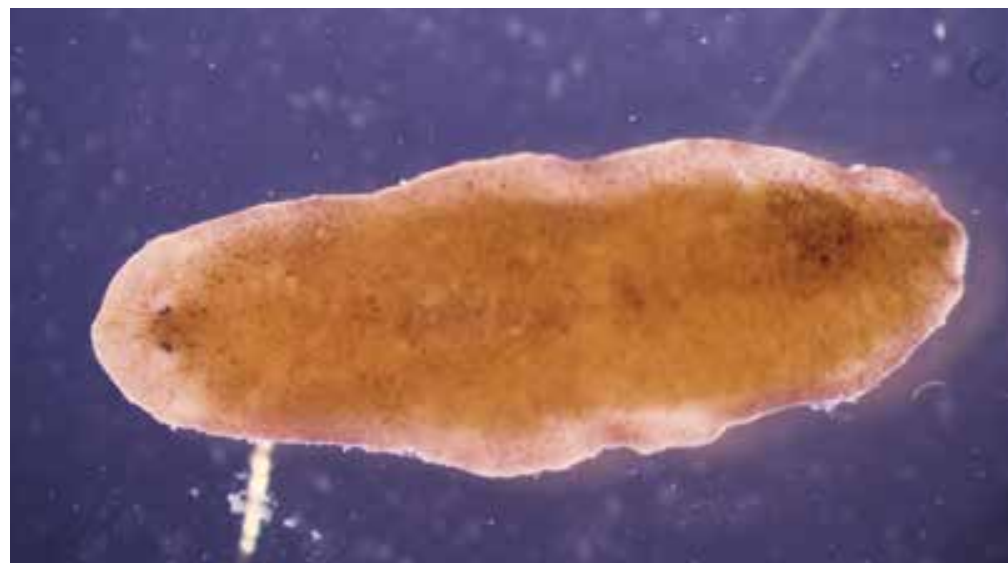

Obr. 2. Nepůvodní druh ploštěnka americká (Dugesia tigrina)

Fig. 2. Immigrant, the North American planarian Dugesia tigrina

Narušení přirozeného vodního toku se dotýká nejen výlučně vodních organismů, ale i těch rostlin a živočichů, kteří mají pouze některou svou životní etapu spjatou s vodním prostředím, ačkoliv nejsou jeho stálými obyvateli. Důležitá je také míra zasažení okolí dané řeky, napríklad zmenšením pravidelně zaplavovaného území. Pravidelné rozlivy jsou pro mnoho druhů rostlin a živočichů potřebné pro jejich šiření a rozmnožování. Pokud k němu nedochází, jedinci nemají dostatek príležitostí k hledání nových vhodných biotopů pro přežití i rozmnožování, což vede k izolaci genofondu populací a ke změnám druhové skladby rostlin a živočichů obývající nivu i príbřežní pásy řek.

\section{METODIKA}

Metodický prístup řešení spočíval v porovnání historických údajů a záznamů z období pred výstavbou vodních nádrží se současným stavem. $V$ rámci řešení projektu byla zpracována rešerše z publikovaných prací, nepublikovaných pramenů a různých studií sahajících až do začátku 20. století. Na základě rešerše vztahující se k zájmovým územím a také s využitím historických mapových podkladů (pokud byly k dispozici v požadované podrobnosti) byla ve vymezeném území, které bylo stanoveno jako oblast zátopy a zóna cca 1 km od břehové linie, provedena rekonstrukce výskytu různých typů vodních biotopů a s nimi spjatých vodních bezobratlých živočichů.

Ze všech zjištěných taxonů bylo vybráno několik typických modelových zástupců, na kterých Ize doložit různé strategie a modelové reakce vodních bezobratlých na důsledky výstavby nádrží. $V$ zásadě bylo možno rozlišit čtyři základní skupiny vodních bezobratlých podle jejich reakce:

A. druhy, které na území dnešních nádrží žily, ale s výstavbou nádrží vymizely i z širšího okolí;

B. druhy, které na území dnešních nádrží žily a s výstavbou nádrží byly vytlačeny do zbytků príirozených habitatů v blízkém okolí;

C. druhy, které na území dnešních nádrži žily a žijí tam i dnes;

D. druhy, které na území dnešních nádrží nežily a vyskytly se tam až po výstavbě nádrží.

\section{VYSLEDKY}

\section{Vranovská přehrada}

Vranovská přehrada je nejstarší ze tři v projektu zkoumaných vodních nádrží. Výstavba díla byla provedena v letech 1930 až 1934. Rozhodnutím o přehradě nad Vranovem byla umožněna výstavba Vranovské přehrady a rozhodnutí zahrnovalo vodoprávní povolení včetně povolení provozu vodní elektrárny (VE Vranov). VE Vranov byla uvedena do provozu v roce 1937 a patří mezi elektrárny, které umožňují doplňovat rozdílnou potřebu energie v průběhu dne výrobou v době tzv. energetické špičky. Zadržování vody a její nárazové vypouštění má však významný negativní vliv z pohledu života v řece pod nádrží, znamená nekončící střídání nízkých hladin s prưtoky bližícími se povodňové úrovni [3, 4].

Vodní nádrž Vranov byla postavena v hlubokém, meandrovitě zakřiveném kaňonu řeky Dyje (obr. 1). Nádrž má výrazně korytovitý charakter, je značně členitá, dlouhá a hluboká. Z hlediska rriční zonace je Dyje v oblasti Vranovské nádrže řazena k epipotamálu, tomu odpovídá rybí pásmo parmové s význačným výskytem druhů ryb ostroretka stěhovavá (Chondrostoma nasus) nebo parma obecná (Barbus barbus). Řeka Dyje pod Vranovskou přehradou má zcela specifický teplotní a průtokový režim - vykazuje charakter podhorského toku [3], který je původnímu stavu dlouhodobě velmi vzdálen. Zelinka a kol. [5] uvádějí letní teplotu vody na lokalitě Podhradí 20,5 C (srpen 1953), pod nádrží však již jen $15^{\circ} \mathrm{C}$. Z hlediska rybích pásem bylo původní pásmo parmové nahrazeno sekundárním pstruhovým pásmem.

Ačkoliv prípravné práce na podkladové dokumentaci k provedení tohoto vodního díla trvaly téměř dvacet roků, botanické a zoologické průzkumy se tehdy jako součást prípravných prací neprováděly. Z meziválečného období existuje jen omezené množství informací o existenci vodních biotopů v této oblasti. Vzhledem ke stárí nádrže Ize brát jako referenční stav krajiny před výstavbou mapový podklad z roku 1876, který však není př́liš podrobný a neumožňuje vyhodnocení podílu akvatických nebo semiakvatických biotopů $\checkmark$ členění, které bylo pro tento účel použito pro nejmladší zde uvedené vodní dílo Nové Mlýny. Zřejmý je pouze podíl vodních ploch (dřive 2,8 \%, nyní 11,5\%) a existence epipotamálního toku řeky Dyje a jejích př́toků charakteru ritrálu (řeka Želetavka a menší potoky).

Výzkumy vodních živočichů, zooplanktonu (živočichů vznášejících se ve volné vodě) a bentosu (organismů obývajících dnové sedimenty) byly v oblasti zahájeny až po napuštění nádrže. Odlehlost nádrže od výzkumných center,

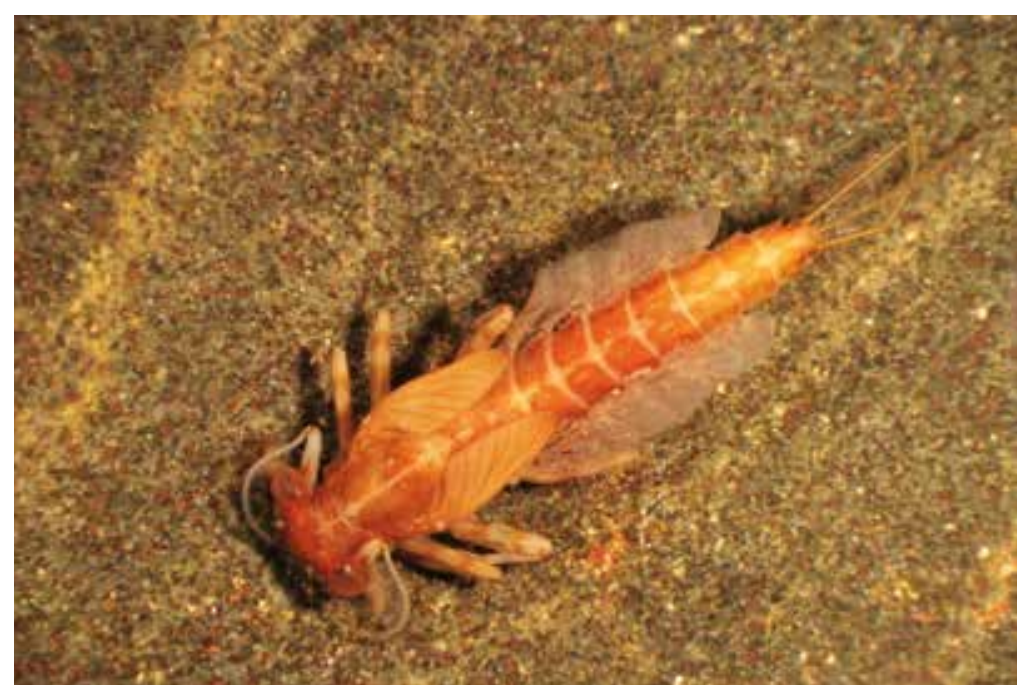

Obr. 3. Velmi vzácný druh jepice podivné (Arthroplea congener), larva

Fig. 3. Very rare species of mayfly Arthroplea congener, larva 
komplikovanost dopravy a možná i válečná léta způsobila, že v prvním desetiletí po napuštění nádrže bylo publikováno jen málo hydrobiologických prací. Nejstarší údaje pochází ze studie autorů Haempel a Stundl [6], kteří studovali nádržz z hlediska rybářského 6 let po jejím napuštění a uvádí šestnáct druhů zooplanktonu, pro makrozoobentos zjistili jen velmi omezené druhové spektrum.

Po druhé světové válce (od r. 1948) byla sledována zejména samotná nádrž, jednalo se o aktivity související s činností tehdejšího hydrobiologického týmu Zoologického ústavu Masarykovy univerzity v Brně pod vedením profesora Sergěje Hraběte (1899-1984). V nádrži samotné byl hodnocen plankton, bentos z hlubších částí nádrže i ryby. Sběry zooplanktonu a bentosu v nádrži prováděli pracovníci a studenti univerzity. V tomto období vznikly dvě diplomové práce, zabývající se výzkumem zooplanktonu nádrže [7, 8], analýzy vzorků zooplanktonu i zoobentosu z období 1950-1951 hodnotila Vlčková [9]. Zásluhou právě profesora Hraběte byla v roce 1952 na zestátněném zámku Bítov zbudována výzkumná biologická stanice, která po určitou dobu sloužila jako základna pro výzkumy vodních organismů. V období činnosti stanice vzniklo několik výzkumných prací. Zooplanktonem nádrže se zabýval Kubíček [10]. Materiál zoobentosu ze sběrů profesora Hraběte z let 1952-1957 a také vlastní sběry z roku 1970 zpracovala Bartáková [11]. Makrozoobentos nádrže byl vyhodnocen jako poměrně druhově chudý, zahrnoval převážně zástupce skupin máloštětinatců (Oligochaeta) a larvy dvou čeledí dvoukřídlého hmyzu: pakomárů (Chironomidae) a pakomárců (Ceratopogonidae).

Sledování ríčního makrozoobentosu v Dyji nad vzdutím Vranovské přehrady i pod ní započalo až v 50. letech 20. století a trvá dodnes. Údaje z lokalit nad nádrží (Dyje od státní hranice po vzdutí nádrže) byly z důvodu absence historic-

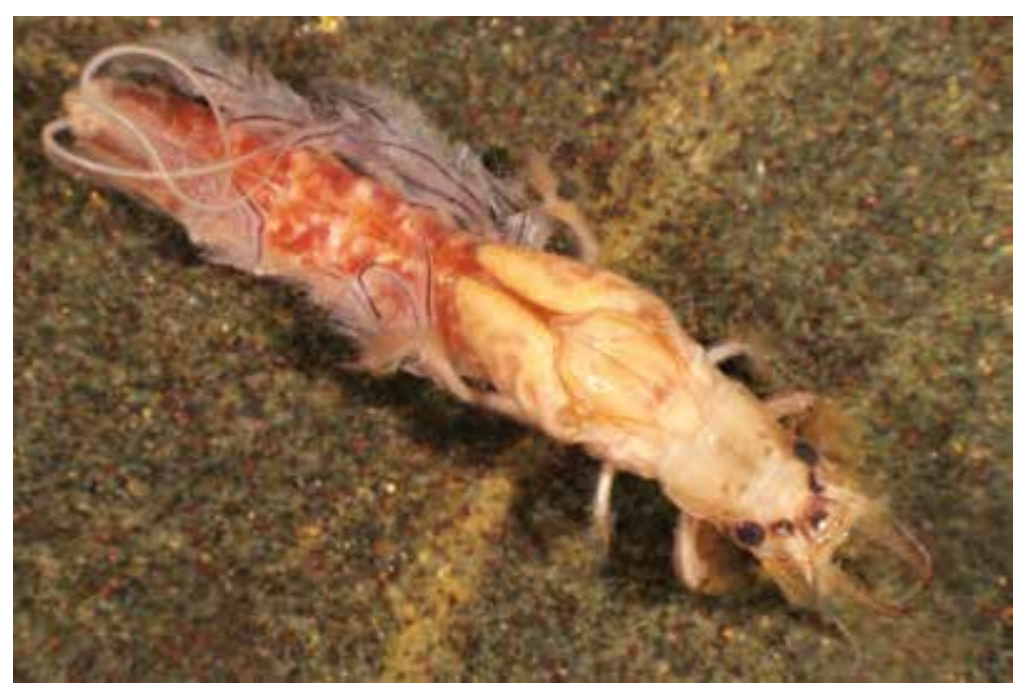

Obr. 4. Larva vzácného, kriticky ohroženého říčního druhu jepice podeňka (Ephoron virgo) Fig. 4. The rare, critically endangered large potamal mayfly Ephoron virgo, larva

kých dat využity pro představu o pưvodním oživení řeky v oblasti zátopy, ačkoliv se jedná o otevřenější údolí. Geomorfologicky bližší zaplavenému území by byl úsek Dyje pod nádrží Vranov v NP Podyjí, ten je však samozřejmě ovlivněn nádrží a provozem vodní elektrárny [12] a pro porovnání je nepoužitelný.

$\checkmark$ rámci výzkumu jakosti vody přehrad $v$ povodí řeky Moravy $v$ polovině 20. století byl sledován makrozoobentos na lokalitách na Dyji, na lokalitě nad nádrží v Podhradí a také pod nádrží i na ústí Želetavky jakožto významného přítoku [5]. V roce 1959 byly studovány významné skupiny vodního hmyzu (jepice, pošvatky a chrostíci) v rámci tajného výzkumného úkolu s označením "210", výsledky viz [13, 14], zčásti nepublikováno.

Lokality nad nádrží i pod nádrží byly od 70. let 20. století sledovány v rámci saprobiologického monitoringu [15], dále $v$ rámci monitoringu hraničních vod pro potřeby výzkumných úkolů VúV TGM a ZVHS (např. [16]) i Rámcového programu monitoringu v souladu s § 13 vyhlášky č. 98/2011 Sb. (výsledky viz http://hydro.chmi.cz/isarrow/).

$\checkmark$ 90. letech 20. století probíhal na lokalitě v Podhradí nad nádrží a na třech lokalitách pod nádrží v NP Podyjí podrobný výzkum vlivu nádrže, zejména vlivu energetického špičkování [17]. Tento výzkum byl zaměřený na makrozoobentos i další složky bioty, v pozdější etapě doplněný i analýzami vzorků z hlubších vrstev dna - hyporeálu [3]. Studie prokázala, že nádrž způsobuje snížení druhové bohatosti v oblasti pod prehradou, v podélném profilu Dyje jsou epipotamální prvky nahrazeny ritrálními druhy. Blešivec potoční (Gammarus fossarum) vytvárí pod nádrží velmi prosperující populace adaptované na extrémní krátkodobé kolísání průtoku, na druhou stranu beruška vodní (Asellus aquaticus), typický druh epipotamálu, má málo početné populace. Také populace menších druhů mlžů jsou v úseku pod přehradou značně početně redukovány (Pisidium sp. a Sphaerium sp.), některé druhy velkých mlžů, četných nad nádrží, zde chybí (rody Anodonta a Unio). Pod nádrží je hlášen nepưvodní druh ploštěnky americké (Dugesia tigrina) - obr. 2.

Na území dnešní nádrže ústily do řeky Dyje prítoky - jednak šlo o řeku Želetavku, jednak o menší potoky: Bítovský p., Dešovský p. a další, tekoucí s poměrně velkým spádem do kaňonu Dyje. Faunu těchto potoků však nemáme z minulosti a ani současnosti doloženou. Na oživení potoků usuzujeme podle stavu v NP Podyjí. Potoky na území NP Podyjí, popř. na jeho hranicích, byly sledovány např. v roce 1993 pro tehdejší Český ústav ochrany prírody, ve druhé polovině 90. let v rámci projektu PERLA [16] nebo později v rámci výzkumů Ústavu botaniky a zoologie Masarykovy univerzity [18-20]. Ty byly orientovány zejména na Gránický potok, jehož charakter v dolním úseku je zřejmě blízký potokům na zkoumaném území.

Výskyt stálých a dočasných stojatých vod v nivě úzkého kaňonu řeky je velmi pravděpodobný, i když nebyly nikdy tak početné jako na níže položeném úseku reky Dyje v oblasti Novomlýnských nádrží. Také zde Ize hledat analogie podle situace v NP Podyjí. Pravděpodobně se jednalo o lesní nebo luční tůně, rybníky a podmáčené louky. Brabec [21] uvádí výskyt vzácného druhu jepice (Arthroplea congener), viz obr. 3, z rybníka mezi Chvalaticemi a Bítovem. Tůněmi v oblasti NP Podyjí se ve své diplomové práci zabývala Kvardová [22], která se věnovala makrozooplanktonu. Z míst, která sledovala, byly zajímavé tůně pod Ledovými slujemi, ty jsou však zjevně antropogenního původu. Uvádí nicméně, že se nacházejí v odříznutém meandru Dyje, takže i tyto biotopy se v úzkém kaňonu mohly nacházet. Pokud tedy Ize usuzovat z analogie s územím NP Podyjí a oblastí

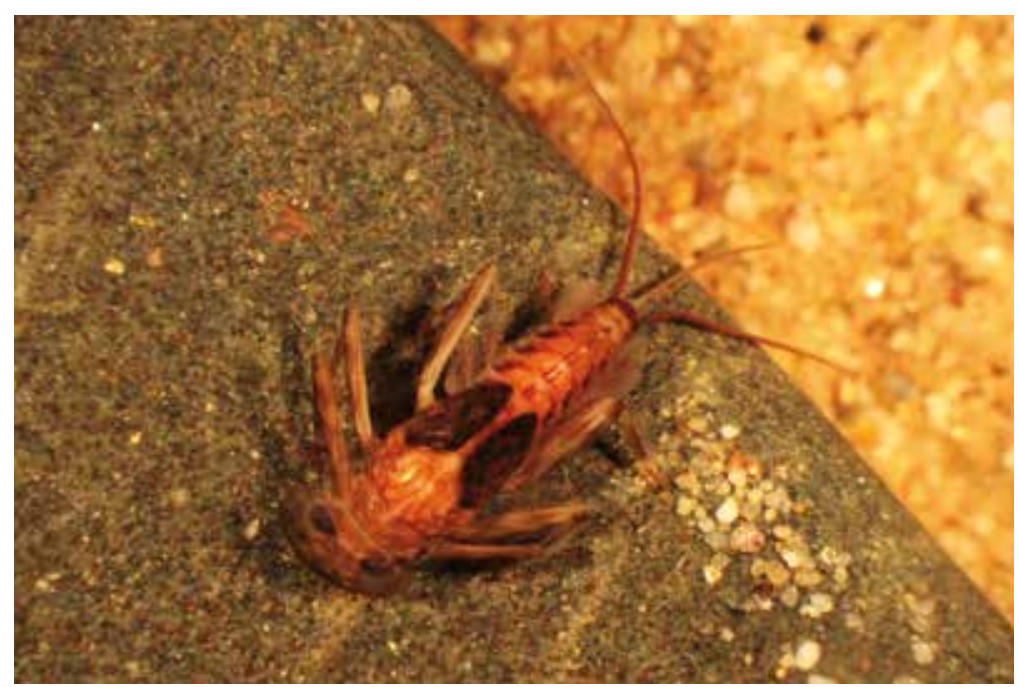

Obr. 5. Larva říčního druhu jepice Ecdyonurus insignis Fig. 5. The riverine mayfly Ecdyonurus insignis, larva 
Znojemska, Ize prepokládat výskyt periodických tůní a v nich několik druhů korýšů: žábronožky sněžní (Eubranchipus grubii), listonoha letního (Triops cancriformis) a možná i žábronožky divorohé (Streptocephalus torvicornis); recentní nálezy [23] však nepochází prímo z kaňonu řeky Dyje v okolí Vranovské nádrže. Bliže k nálezům velkých lupenonohých korýšů v ČR, mezi něž výše uvedené druhy patří, je uvedeno v práci Merta a kol. [24].

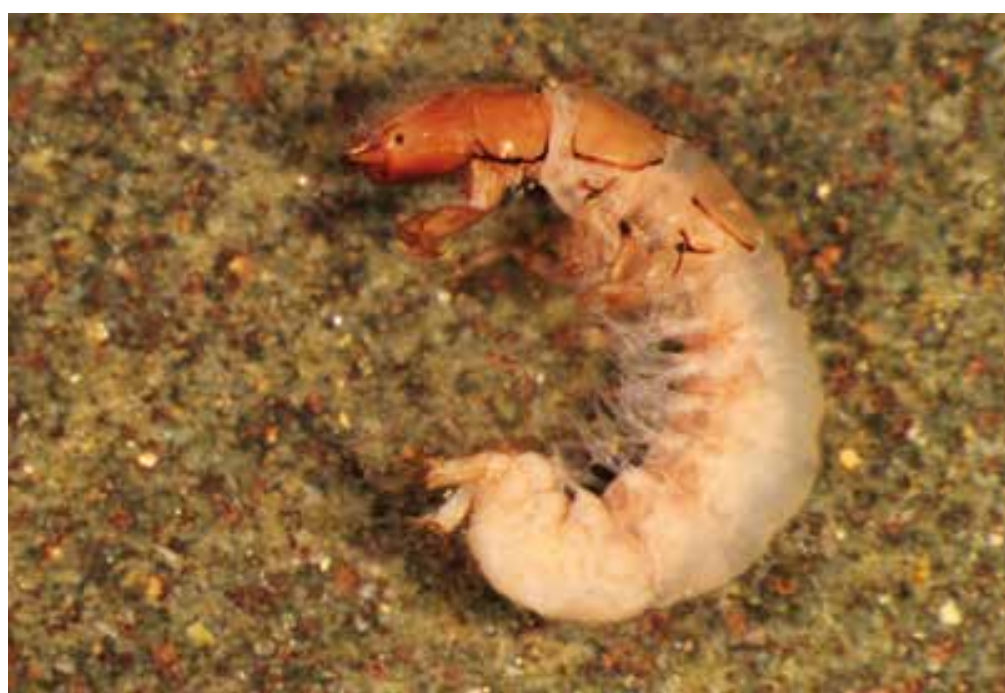

Obr. 6. Larva říčního druhu chrostík Cheumatopsychelepida

Fig. 6. The riverine caddisfly Cheumatopsychelepida, larva

Společenstva vodních organismů žijící nad nádrží, v nádrži a pod nádrží Vranov se od sebe značně liší. Teplomilné a citlivé druhy živočichů, které dřive v řece žily, mizí z velkých řek všeobecně a zničení části biotopů s jejich výskytem zaplavením tento proces ještě posiluje. Podrobnější posouzení změn ve výskytu druhů je obtížné vzhledem k nedostatku historických dat, zejména o makrozoobentosu i fauně tůní (nejlépe podchycenou skupinou jsou Ephemeroptera). V zásadě jsou možné tyto následující změny ve výskytu druhů:

A. Druhy, které na území dnešních nádrží žily, ale s výstavbou nádrží vymizely i z blízkého okolí: Potamální, kriticky ohrožený [25] druh jepice Ephoron virgo (obr. 4) se na lokalitě Podhradí vyskytoval ještě na konci 90 . let. Jeho vymizení ve studované oblasti koresponduje se stavem v ostatních velkých řekách v ČR. Druh se před výstavbou nádrže jistě vyskytoval i v oblasti zátopy, jeho vymizení i v úseku nad nádrži však nelze vztahovat výlučně k existenci nádrže. Ta však způsobila zánik funkčních vazeb a biotopů, ve kterém se populace citlivého druhu mohla udržet.

B. Druhy, které na území dnešních nádrži žily a s výstavbou nádrží byly vytlačeny do zbytků prírozených habitatů v blízkém okolí: Dva druhy jepic, Ecdyonurus insignis (obr. 5) a Heptagenia flava, které se v současnosti na lokalitě Podhradí vyskytují, ale E. insignis nebyl již níže v řece Dyji zjištěn; $H$. flava byla recentně zjištěna až na lokalitě cca 20 km pod hrází níže položené Znojemské nádrže. Podobně je na tom chrostík (Cheumatopsyche lepida), viz obr. 6, který dodnes žije nad nádrží, ale prímo v nádrži a v chladné řece pod hrází se nevyskytuje. Odolnější druhy se mohou nahodile vyskytovat pod nádrží, aniž by ovšem dokončovaly životní cyklus (jepice Potamanthus luteus). Druhy eurytermní, jako např. plž (Ancylus fluviatilis), viz obr. 7, který sice také nepřeživá přímo v nádrži ale vyskytuje se v úseku pod hrází nebo v prítoku - Želetavce. Druhy mlžů maji pod nádrží snížené početnosti jedinců, rody Anodonta (obr. 8) a Unio (obr. 9) se nevyskytují [3].
C. Druhy, které na území dnešních nádržížily a žijí tam i dnes: Mimo plankton je tato skupina zastoupena především některými druhy pakomárů (Chironomidae) a máloštětinatců (Oligochaeta), tedy organismy obývajícími dno tekoucích vod i nádrží (Limnodrilus sp., Tubifex sp. aj.).

D. Druhy, které na území dnešních nádrží nežily a vyskytly se tam až po výstavbě nádrží: Silně změněné poměry v řece pod nádrží znemožňují život některým organismům. Toho využívají ty odolnější. V oblasti se objevily nepůvodní druhy, to však zřejmě nelze považovat za prímý vliv nádrže, např. ploštěnka (Dugesia tigrina) - obr. 2, nebo plž levatka (Physella acuta) - obr. 10. Korýš Gammarus fossarum byl zajisté prítomen v řece i před výstavbou nádrže, jeho početnost se však v úseku ovlivněném energetickým špičkováním mnohonásobně zvýšila.

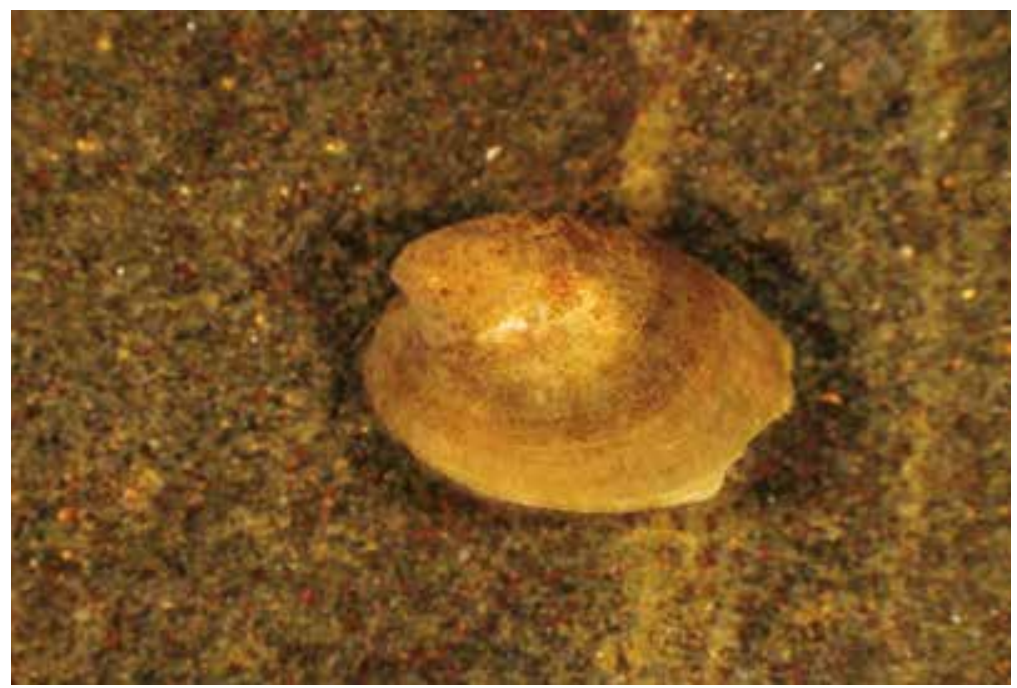

Obr. 7. Plž kamomil říční (Ancylus fluviatilis)

Fig. 7. Ancylus fluviatilis is a species of very small, freshwater, air-breathing limpet

Za nejvýraznější vliv nádrže na dotčené území Ize označit zánik mimořádného typu toku - potamálního úseku řeky tekoucí v kaňonu, a to nejen na zaplaveném území, ale i v cenném území národního parku, kde se řeka zcela liší od přirozeného stavu $v$ důsledku zejména silně ovlivněného průtokového režimu a teplotního režimu. V prípadě nádrže Vranov, řeky Dyje v NP Podyjí a navazující nádrže Znojmo to predstavuje minimálně 70 říčních kilometrů se zcela změněným charakterem toku, který patřil v evropských podmínkách k obzvláště hodnotným. Paradoxně tedy máme v území s nejvyšším statutem ochrany prírody řeku, která je svým oživením velmi vzdálená přirozenému stavu.

\section{Brněnská přehrada}

Vodní dílo Brněnská přehrada bylo postaveno v letech 1936-1940. Řeka Svratka měla tehdy $\vee$ oblasti dnešní zátopy z hlediska geomorfologie a teplotních poměrů charakter odlišný od vyšších, ale i nižších úseků toku. Tekla zde převážně $v$ úzké údolní nivě a pouze $v$ oblasti horního konce vzdutí meandrovala (obr. 11 a 12). Řeka ve výchozím stavu nejspíše predstavovala prechod mezi chladnějši ríční zónou (ritrál) a zónou teplejší (potamál). V Zelinkově studii [5] je jako maximální teplota vody nad nádrží uvedena hodnota $20,5^{\circ} \mathrm{C}$, což odpovídá dolní hranici pro nejvyšší část potamálu (epipotamál), tedy parmovému pásmu. Od 50. let 20. století je pak řeka Svratka v úseku nad Brněnskou přehradou ovlivněna z hlediska průtokového i teplotního režimu výše položenými nádržemi Vír I a Vír II, uvedenými do provozu v letech 1954 a 1957. Brabec [26] uvádí, že maximální letní teploty nad nádrží byly nižší než $18^{\circ} \mathrm{C}$ a odpovídaly ( $v$ letech sledování 1992-1993) zóně metaritrálu, tedy střední zóně ritrálu, teploty pod 
nádrží se pohybovaly kolem $19^{\circ} \mathrm{C}$. Z rozdílů Ize usuzovat na teplotní ovlivnění řeky vlivem nádrží Vír a na určité snižení letních maxim i v toku pod nádrží Brno.

Podobně jako u nádrže Vranov je analýza původního zastoupení akvatických a semiakvatických biotopů v oblasti dnešní Brněnské nádrže a jejího blízkého okolí obtížná. Z existujících map Ize usuzovat jen na nárůst podílu vodních ploch před a po výstavbě nádrže - z 2\% v roce 1876 na cca $10 \%$ v roce 1953 a tento podíl v podstatě zůstává zachován do současnosti. Podrobné mapové podklady pro zjištění výskytu různých typů vodních biotopů chybí. Z historických literárních pramenů Ize soudit na existenci mrtvých říčních ramen, periodických tůní a rybníka v blízkosti hradu Veveři kolem roku 1920 [27, 28].

Na počátku 30. let hodnotil řeku Svratku z hlediska hygienického Roček [29]. Řeku rozdělil na úseky. V úseku, který začínal nad Veverskou Bítýškou a končil bývalou obcí Kníničky, popisuje Svratku jako řeku protékající krásným, bohatě zalesněným horským údolím, která však měla hygienickou jakost vody ovlivněnu odpadními vodami města Tišnova, obcí Veverskou Bítýškou a průmyslovým znečištěním z koželužny a papírny. $V$ řece probíhaly intenzivní samočisticí procesy a výsledky hydrochemických a mikrobiologických analýz se měnily zejména v závislosti na průtočném množství vody $v$ řece. Kvalita vody už tenkrát nebyla príliš dobrá, Roček ji charakterizuje jako průměrnou, mesosaprobní. Biologické rozbory byly omezeny na plankton (organismy vznášející se ve volné vodě), uvádí např. výskyt ploštěnky Stenostomum leucops, perloočky Bosmina longirostris, máloštětinatce rodů Chaetogaster a Nais a drobných larev hmyzu bez bližšího určení. Oživení reky bentickými bezobratlými zřejmě nebylo před výstavbou nádrží sledováno.

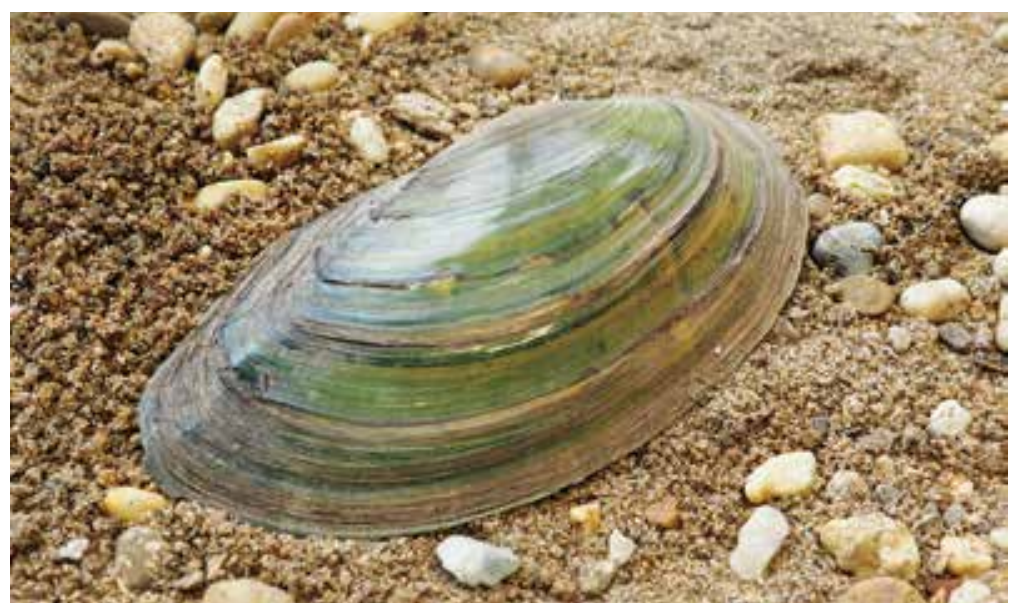

Obr. 8. Mlž škeble rybničná (Anodonta cygnea)

Fig. 8. The swan mussel, Anodonta cygnea, is a large species of freshwater mussel

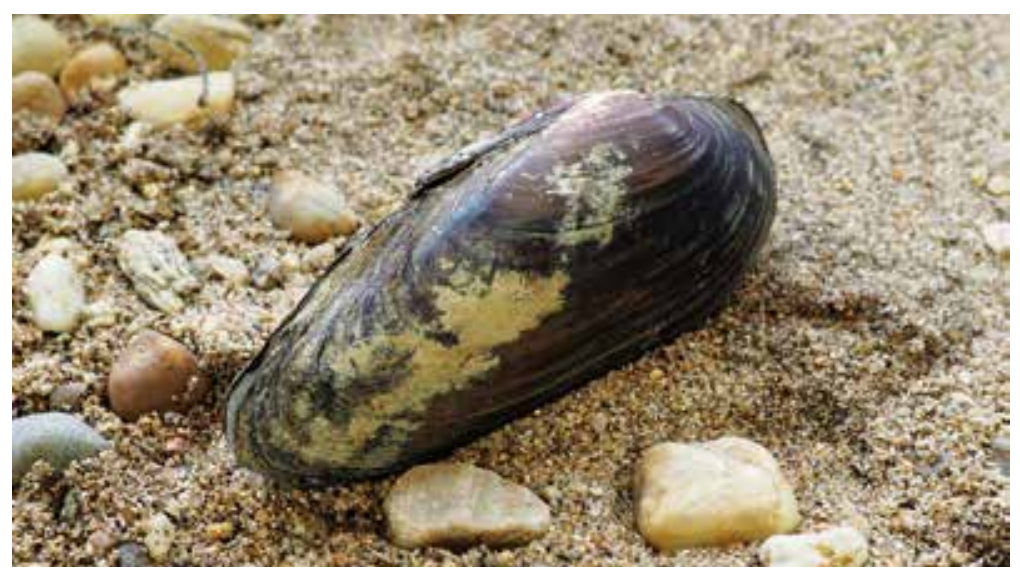

Obr. 9. Mlž velevrub malî́ský (Unio pictorum)

Fig. 9. The painter's mussel, Unio pictorum, is a species of medium-sized freshwater mussel

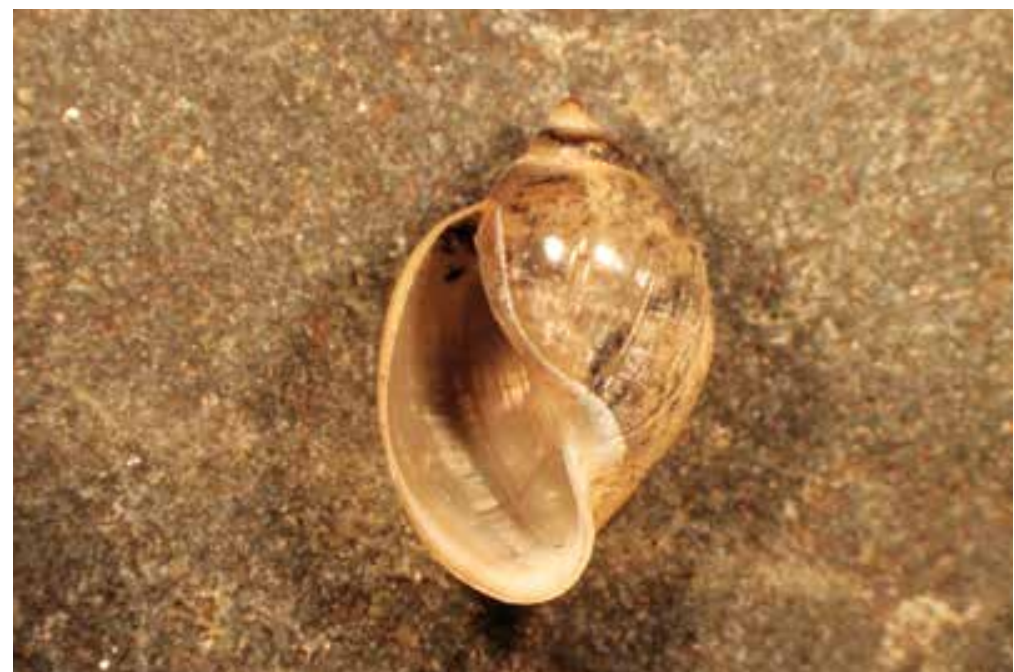

Obr. 10. Nepůvodní plž levatka (Physella acuta)

Fig. 10. Physella acuta is a small, left-handed or sinistral, air-breathing freshwater snail

Studiem oživení v nádrži se v poválečném období jako první zabývali studenti Musil a Procházka v diplomové práci, věnované zooplanktonu [30]. Losos [31] studoval planktonní společenstva (mimo vírníky) a bentos (organismy žijící u dna) nádržee, okrajově se věnoval i fauně obývající príbřežní vegetaci (litorál) nádrže, která by teoreticky mohla být nejbližší původním říčním společenstvům. Podle jeho nálezů byla společenstva bentických bezobratlých velmi chudá, tvořená z 98 \% máloštětinatými červy (Oligochaeta) a larvami pakomárovitých (Chironomidae), zástupci ostatních živočišných skupin tvořily menšinu. Běžné říční druhy hmyzu se nevyskytovaly. Poukazuje na jednotvárný obraz sedimentů u dna nádrže a neklidné stanovištní podmínky u břehů (silně kolísající hladina), které způsobují slabé rozvinutíl litorální zóny a druhovou chudost vegetace i bentické fauny. Nádrž celkově charakterizuje jako eutrofní. Informativní a pak i podrobnější výzkum nádrže včetně př́toku a odtoku provedl Zelinka a kol. [5, 32]. Ve vlastní nádrži zjistil běžné druhy planktonu, z makroskopických bezobratlých obývajících dno nad nádrží uvádí taxony: plže kamomila říčního (Ancylus fluviatilis), viz obr. 7, pijavku hltanovku bahenní (Erpobdella octoculata) a chobotnatku plochou (Glossiphonia complanata), korýše blešivce hřebenatého (Gammarus roeselii) a berušku vodní (Asellus aquaticus), jepice Potamanthus luteus, Ecdyonurus sk. venosus, Baetis sp., Ephemerella ignita a Caenis sp., pošvatku Perla abdominalis, chrostíky Rhyacophila nubila, Hydropsyche sp., a zástupce čeledi pakomárovití (Chironomidae).

Z úseku Svratky v Tišnově, tedy nad již existující nádrží Brněnskou, ale pravděpodobně ze sběrů ještě před uvedením do provozu nádrže Vír l, uvádí Zelinka a Skalníková [33] druh jepice Ephemerella notata (obr. 13), který byl již tehdy označen v povodí Moravy jako vzácný. Dále uvádí zmínku o výskytu jepice druhu Potamanthus luteus. Tento řiční druh se do nádrže dostal ž̌ejmě z výše položeného úseku řeky Svratky, protože jeho výskyt $v$ menších prítocích $v$ okolí nádrže je nepravděpodobný a migrační schopnosti této skupiny jsou omezené. Svratku v úseku nad i pod nádrží sledoval v letech 1992-1993 Brabec [26]. Z lokality Veverská Bítýška neuvádí ani jeden z dvou výše uvedených druhů jepic, zato nalezl dřive na lokalitě nezjištovaný druh jepice Oligoneuriella rhenana (obr. 14). Tento druh nebyl v posledních letech zjištěn, má však krátké období výskytu ve vodě, navíc mimo obvyklé termíny odběrů vzorků a může tedy unikat pozornosti. Autor dále zjistil několik druhů pošvatek rodu Leuctra, dále Perla burmeisteriana, Perlodes microcephalus a Isoperla rivulorum, které jsou nalézány i v posledním období, tj. po roce 2000 (http://hydro.chmi.cz/isarrow/), stejně jako opět se vyskytující jepice Potamanthus luteus. Makrozoobentos lokality celkově vykazuje směs druhů ritrálu a potamálu. 


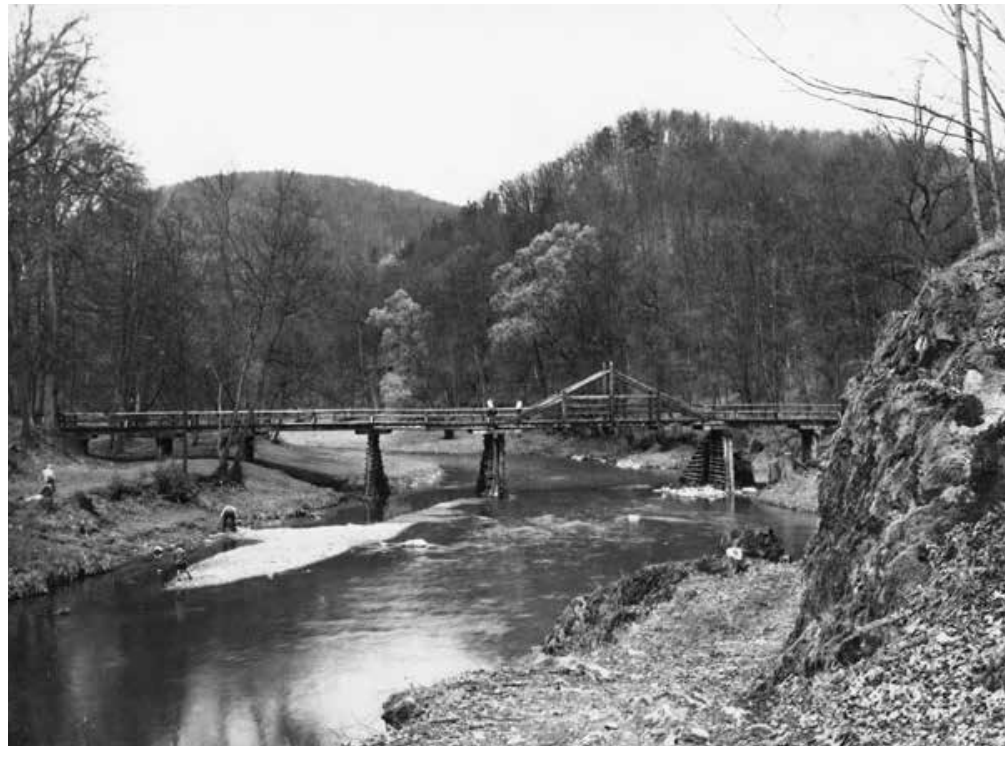

Obr. 11. Most přes řeku Svratku v horní části dnešní zátopy - nad Roklí

Fig. 11. The bridge over the Svratka River - the upper part of a flooded area

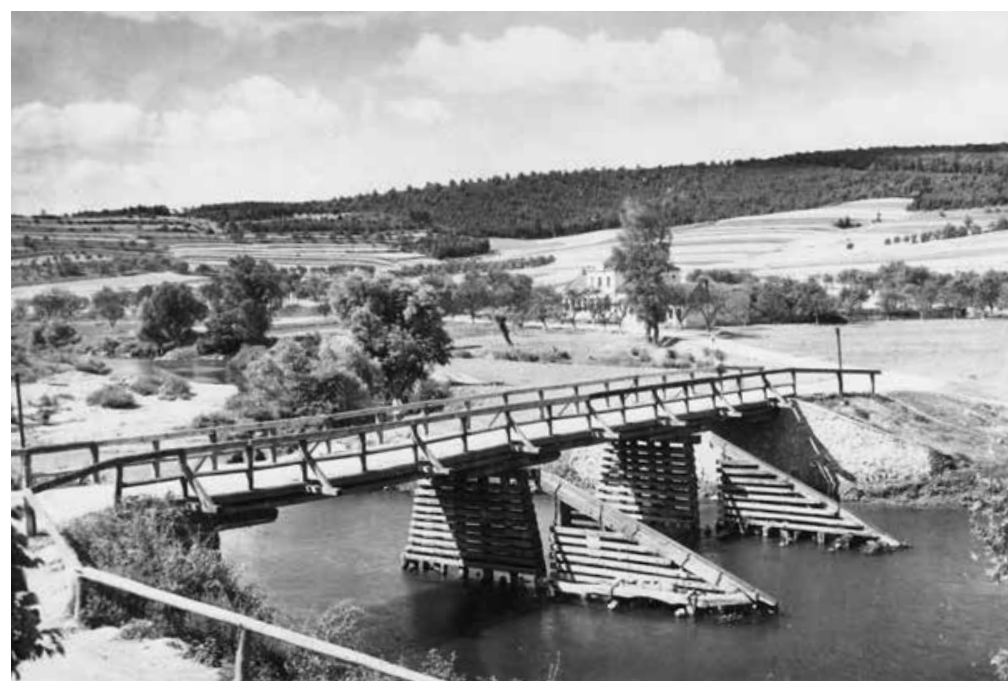

Obr. 12. Řeka Svratka ve starých Kníničkách v oblasti dolní zátopy Brněnskou přehradou Fig. 12. The Svratka River in former Kníničky village - the lower part of a flooded area

Hrabě [34] popsal z této nádrže nález nepůvodní mechovky Pectinatella magnifica, $v$ dalším období podrobně studoval faunu litorálu nádrže [35]. Sledoval osm lokalit v dolní části nádrže, u přehradní hráze, v úrovni Sokolského zálivu na levém břehu a Kozí horky na pravém břehu. Během ročního výzkumu zjistil celkem 102 taxonů, z toho 35 z čeledi pakomárovitých. Druhově nejbohatší byla lokalita při ústí potůčku na konci Sokolského zálivu, která se od ostatních sledovaných míst značně odlišovala, a př́tomnost některých druhů, např. chrostíka druhu Potamophylax nigricornis nebo blešivce potočního (Gammarus fossarum), ukazuje na ovlivnění prítokem. Zooplanktonem se zabýval Šrámek-Hušek [36, 37] a Kubíček [38].

Vodami nádrže byly zaplaveny většinou krátké úseky př́toků - potoků, pouze v prípadě potoka Rakovec byl zaplaven delší úsek (potok ústil do Svratky v blízkosti dnešní hráze). O potoční fauně však nebyly nalezeny žádné historické údaje. Studiu potoků v brněnském okolí bylo později věnováno několik diplomových prací Ústavu botaniky a zoologie MU v Brně, ale až od 60. let 20. století. Jedna z nich byla věnována potoku Veverka, ústícímu do nádrže [39].

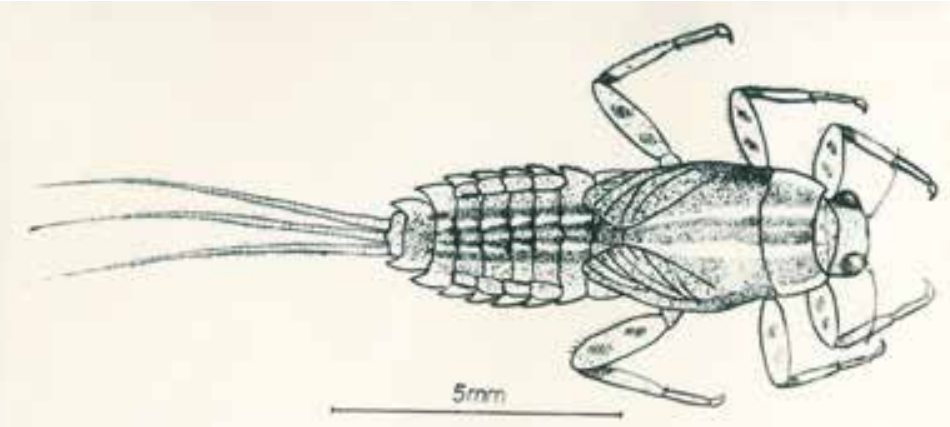

Obr. 13. Larva vzácného druhu jepice Ephemerella notata (fotografie: J. Halouzka) Fig. 13. Very rare riverine mayfly Ephemerella notata, larva (photo J. Halouzka)

Materiál z tůní, louží, příkopů sbíral patrně v inundačním území Svratky v okolí Veveří Spandl. Zcela určitě sbíral také v rybnících u Veveří a v louži u pramene při ústí Veverky. V blízkosti řeky Svratky na území Brna sledoval také tůně mezi Bystrcí a Komínem a na Žlutém kopci [27, 28, 40, 41]. Autor uvádí nálezy listonohů Branchipus schaefferi (obr. 15) ve velkých množstvích, dále žábronožek Eubranchipus grubii, lasturnatek Herpetocypris reptans a Cyclocypris laevis, u kriticky ohroženého druhu Cyzicus tetracerus (obr. 16) však uvádí, že nebyl zjištěn od roku 1915. Přímo z okolí hradu Veveří udává výskyt lasturnatky Notodromas monacha. V tůňkách v oblasti záplavy je také pravděpodobný výskyt jepice Siphlonurus armatus, který je udáván jako $v$ té době obecně hojný v rybnících i periodických tůňkách, imaga byla chycena na blíže neurčené lokalitě v roce 1949 a za Komárovem (část Brna) v roce 1952 [33].

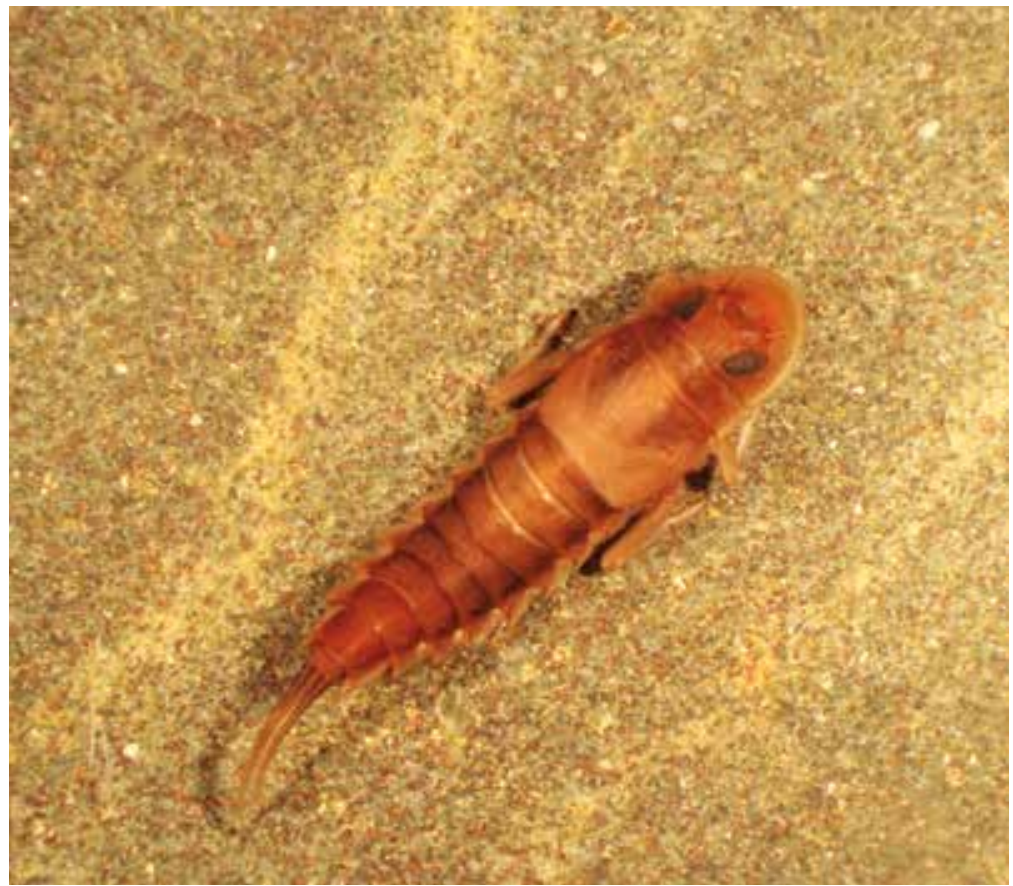

Obr. 14. Larva proudobytné jepice sporožilné (Oligoneuriella rhenana)

Fig. 14. Larva of Oligoneuriella rhenana is rheobiont 


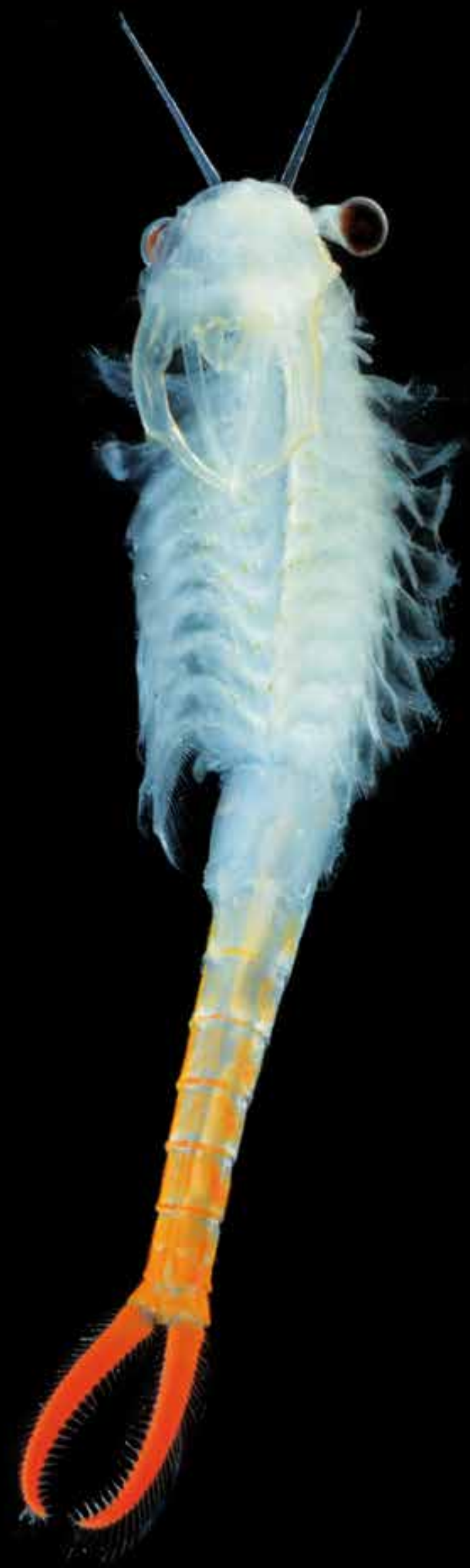

Obr. 15. Kriticky ohrožený korýš periodických vod žábronožka letní (Branchipus schaefferi) (fotografie: L. Merta)

Fig. 15. The critically endangered crustacean of periodic pools - fairy shrimp (Branchipus schaefferi) (photo: L. Merta) 
Podrobnější posouzení změn ve výskytu druhů je poměrně obtížné vzhledem k nedostatku dat. Existují však údaje z 50. let 20. století, které zachycují stav $\checkmark$ úseku nad Brněnskou nádrží a to ještě preed ovlivněním nádržemi Vír I. a II. Tento stav Ize považovat za blízký stavu říčního makrozoobentosu v zaplaveném úseku, a proto byl pro posouzení změn využit. Druhy vodních bezobratlých živočichů byly s ohledem na jejich ovlivnění vybudováním nádrže a jejich schopnost prizpůsobit se novým podmínkám rozděleny do čtyř skupin:

A. Druhy, které na území dnešních nádrží žily, ale s výstavbou nádrží vymizely i z blízkého okolí: Do této skupiny patři druh jepice Ephemerella notata (obr. 13), který byl nalézán sporadicky na jiných tocích ještě v 80 . letech, a v současnosti je jeho výskyt znám z několika málo míst. Také jepice Ecdyonurus insignis (obr. 5) v současnosti ve sledované oblasti již není nalézána. Není také hlášen výskyt živočichů obývajících periodické tůně, jako jsou např. žábronožka sněžní (Eubranchipus grubbii), žábronožka letní (Branchipus schaefferi), viz obr. 15, nebo listonoh jarní (Lepidurus apus), viz obr. 17, tedy druhy, které jsou recentně zjištovány i v oblastech nepř́liš vzdálených, např. na Břeclavsku či Znojemsku [22]. Do této skupiny patři také kriticky ohrožený korýš škeblovka oválná (Cyzicus tetracerus), viz obr. 16, která dřive žila v tůních v údolí Svratky, vymizení tohoto druhu však nelze dávat do př́mé souvislosti s výstavbou nádrží.

B. Druhy, které na území dnešních nádrží žily a s výstavbou nádrží byly vytlačeny do zbytků prírozených habitatů v blízkém okolí: Patří sem většina říčních druhů, které jsou nalézány v úseku nad vzdutím nádrže i níže pod hrází. Druhy potoční mají možnost přežívat ve vyšších úsecích toků. Oblast je sice intenzivně rekreačně využívaná, ale stav potoků není príliš ovlivněný (plž kamomil řční Ancylus fluviatilis (obr. 7), pijavky Erpobdella octoculata a Glossiphonia complanata (obr. 18), korýši blešivci Gammarus fossarum a Gammarus roeselii, jepice Potamanthus luteus a Ephemerella ignita, chrostík Rhyacophila nubila aj.).

C. Druhy, které na území dnešních nádrží žily a žijí tam i dnes: Mimo zooplankton, vyskytující se dřive v blízkých rybnících, mohou v nádrži přežívat limnofilní říční a potoční druhy, zejména $v$ litorálu a blízkosti př́toků, například druhy jepice rodu Caenis, beruška vodní (Asellus aquaticus) a pijavky [35].

D. Druhy, které na území dnešních nádrží nežily a vyskytly se tam až po výstavbě nádrží: Takovým druhem je pravděpodobně teplomilný druh zooplanktonu, perloočka ramenatka velká (Leptodora kindtii), viz obr. 19, kterou Spandl [40] nalezl v umělé nádrži u Kamenného mlýna, v přirozených biotopech však nikoliv, pričemž její tehdejší nejbližší výskyt uvádí 35-40 km severně a severovýchodně od Brna. Druh makrozoobentosu príslušný do této skupiny se nepodařilo spolehlivě zjistit.

Řeka Svratka měla v oblasti zátopy z hlediska geomorfologického typu a teplotních poměrů charakter odlišný od vyšších i nižších úseků toku, přechodné biotopy zde existující byly výstavbou nádrže zničeny. Průtokový režim nádrže není natolik devastující, jako je tomu u Vranovské přehrady, nicméně i zde je v provozu elektrárna a průtokový režim toku pod nádrží je změněný. Navíc řeka pod nádrží protéká městskou aglomerací, je znečištována a téměř po celé dalši trase regulována. Návrat $k$ přirozené diverzitě biotopů v řece i nivě stejně jako diverzitě jejich oživení je prakticky znemožněn až k oblasti dalšího hodnoceného vodního díla Nové Mlýny, do jehož střední zdrže řeka Svratka ústí.

\section{Vodní dílo Nové Mlýny}

Oblast soutoku tři větších, původně meandrujících nížinných řek - Dyje, Jihlavy a Svratky - byla před výstavbou nádrží z velké části tvořena lužním lesem, početnými mokřady, stálými i periodických tůněmi a podmáčenými loukami.

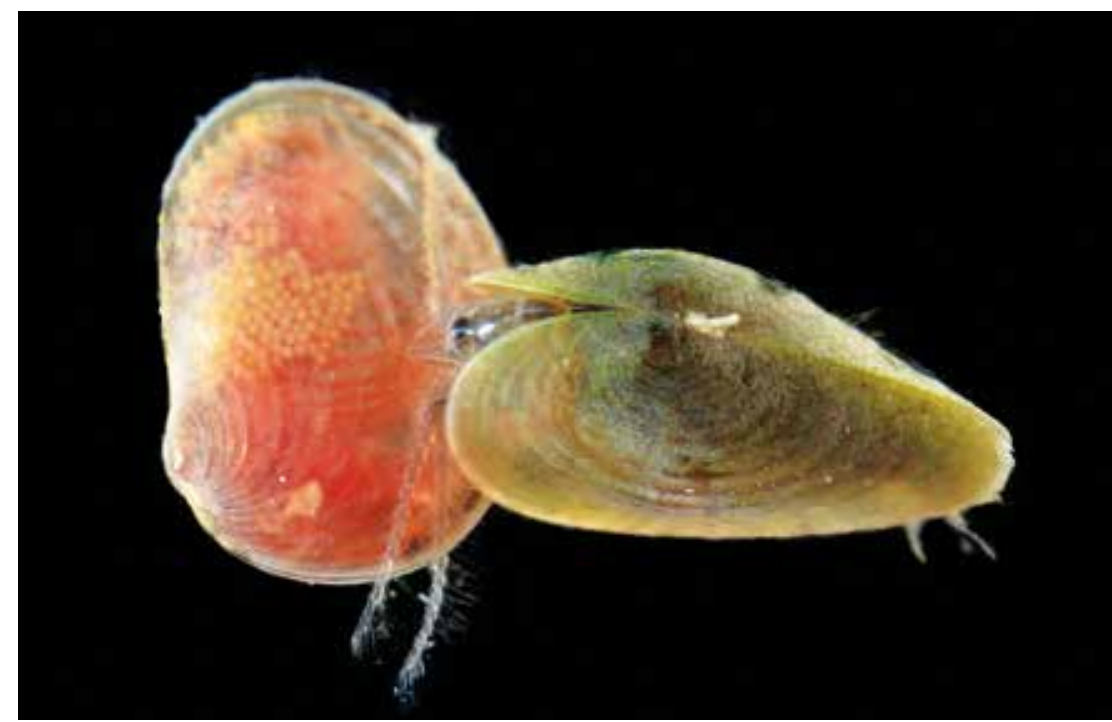

Obr. 16. Kriticky ohrožený korýš periodických vod škeblovka oválná (Cyzicus tetracerus) (fotografie: L. Merta)

Fig. 16. The critically endangered crustacean of periodic pools, large branchiopods cyzicus tetracerus (photo: L. Merta)

Vývoj meandrující řeky dává vzniknout ramenům, která se postupně oddělují od hlavního toku a zazemňují se. Přirozenými procesy tak v nivě vzniká nerovný povrch a snížená místa jsou zaplavována vodou z průsaků, rozlivy př̀ záplavách i ze srážek, a to jak v jarním období, tak i v letním až podzimním období. $\checkmark$ některých místech voda zůstává celoročně, v některých jen dočasně. Stojaté vody v nivě tak mají v zásadě charakter periodických nebo permanentních tůní (obr. 20). Typickým prostředím jsou zde také podmáčené louky, které bývají při povodni a určitou dobu po ní i zaplaveny. Při intenzivních srážkách vznikají rozlivy i na polích. Vzniká tak pestrá a dynamická mozaika vnikajících a zanikajících biotopů pro různé druhy organismů. V přirozeném stavu zánik určitého biotopu nic závažného neznamená, protože v blízkosti již existují další místa s obdobnými podmínkami.

Na řekách v této oblasti nebyly v prírodě blízkém stavu žádné př́ičné překážky, které by omezovaly nebo znemožňovaly pohyb vodních organismů. Řeky a také jejich nivy byly tedy velmi propojenými systémy, které umožňovaly snadné šíření organismů. To se běžně děje po proudu, ale do určité míry i proti proudu řek, a to bud prímo ve vodě, nebo i vzdušnou cestou (dospělci vodního hmyzu nebo pasivním přenosem, např. prostrednictvím ptáků nebo větru). Záplava při povodni propojuje celý systém i do šírky - laterálně. Organismy putují i na větší vzdálenosti, voda přenáší i vajiččka živočichů a semena rostlin a ty tak mají šanci se v prostředí pro ně vhodném udržet.

V unikátní krajině meandrujících řek a lužních lesů v jejich nivách však došlo již v 19. století k významným změnám struktury biotopů. V oblasti už tehdy probíhaly významnější vodohospodářské úpravy včetně regulací a překládek říčních toků, budování odvodňovacích kanálů a protipovodňových hrází. Technické zásahy vyvrcholily výstavbou vodního díla Nové Mlýny (VD NM) v letech 1975 až 1989, které prakticky zlikvidovalo území lužních lesů, velmi významně ovlivnilo krajinný ráz a prírodní podmínky zátopy i blízkého okolí. Významně se tak změnila struktura vodních biotopů $v$ celé oblasti.

Díky relativně nedávné historii výstavby a značné pozornosti věnované tomuto od počátku kontroverznímu vodnímu dílu máme poměrně dobrou představu o výskytu rozličných vodních biotopů a s nimi spjatých vodních organismů. Pro posouzení rozsahu změny vlivem VD NM byla provedena rekonstrukce výskytu vodních biotopů za použití vojenské mapy z let 1952-1957, na které byly vyznačeny periodické tůně, mokřady, podmáčené louky, slepá a mrtvá říční ramena, rybníky a další stanoviště, která s výstavbou vodního díla nenávratně 
zanikla. Protože výstavba nádrží měla a má vliv nejen na území v současnosti zatopené vodou, ale i na jeho okolí, hodnotili jsme nejen oblast zátopy, ale i zónu cca 1 km od břehové linie s rozšířením v oblasti soutoku Svratky a Jihlavy, kde leží významná lokalita na řece Jihlavě u obce Ivaň [42]

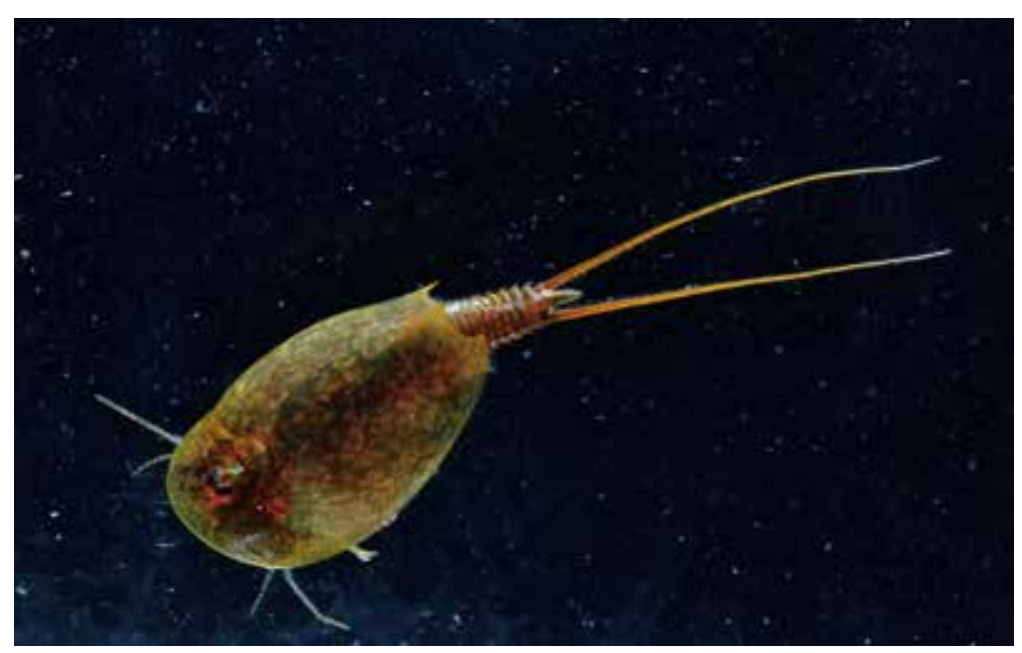

Obr. 17. Korýš periodických vod listonoh jarní Lepidurus apus (fotografie: L. Merta)

Fig. 17. Tadpole shrimp, Lepidurus apus, inhabits periodic pools (photo: L. Merta)

Pro hodnocení změny byli sledováni vodní bezobratlí a za tímto účelem byla zpracována rešerše z publikovaných prací, nepublikovaných pramenů (převážně diplomových prací studentů Prírodovědecké fakulty Masarykovy univerzity) a různých studií sahajících až do poloviny 20. století. Výzkum v daném území před počátkem stavby byl významně podpořen existencí terénní biologické stanice v Mušově. Studie stavu po výstavbě se věnují převážně situaci prímo v nádržích, popř. toku Dyje pod VD NM, a tedy spíše širšímu okolí mimo zde definovanou oblast blízkého okolí. Na těchto výzkumech mají mimorádné zásluhy pracovníci dnešní Mendelovy univerzity $v$ Brně, kteří dlouhodobě působili v hydrobiologické laboratoři v Lednici (Ivo Sukop - fauna a Jiří Heteša flóra). Jejich studie z oblasti Lednicko-valtického areálu anebo oblasti soutoku Moravy a Dyje pod Břeclaví mohou také poskytnout predstavu o analogických biotopech, které se nacházely v oblasti dnešního VD NM, např. [43].

Prací ze sousedících oblastí, tedy širšího okolí VD NM, které by byly využitelné tímto srovnávacím způsobem, je celá řada, at’ už se jedná o údaje o makroskopicky rozlišitelných bezobratlých obývajících dno (makrozoobentos), nebo o korýších volně se vznášejících ve vodním sloupci stojatých vod (zooplankton) či specifické skupině obyvatel vysychajících (periodických) vod, která je tvořena opět především korýši (zejména žábronožky a listonozi). Dobře je zpracována např. skupina měkkýšů, pro které existují informace dokonce i z 19. století. Beran a Horsák [44] publikovali článek o vodních měkkýších Dolnomoravského úvalu, $\checkmark$ němž jsou shrnuty i starší informace, bohužel však jde o lokality vzdálené od území VD NM a jen zčásti zasahující do jeho širšího okolí. Informačním zdrojem tohoto typu je také monografie o vodních bezobratlých Biosférické rezervace Pálava [45].

Pokud jde o samotné sledované území, tedy plochu VD NM a jeho blízkého okolí, tak z období před počátkem budování VD NM pochází práce Kubíčka [46], který zpracoval vlastní, ale i Hrabětovy a Valouškovy sběry ze 12 lokalit periodických vod v inundační oblasti řek Jihlavy, Svratky a Dyje v oblasti Vranovic, Pouzdřan, Ivaně a Mušova. Vzorky byly odebírány z lučního príkopu, mělkých tůní, v louce rozlitého slepého ramene. Autor sledoval zejména zooplankton a v oblasti Mušova zjistil výskyt vzácné perloočky Daphnia atkinsoni, uvádí však i výskyt žábronožky sněžní (Eubranchipus grubii) a různé druhy makrozoobentosu. Valoušek [47] v samostatné publikaci pak popisoval periodickou sněžní tůn̆ jako biotop a uváděl i konkrétní lokality a jejich oživení ze zájmové oblasti.

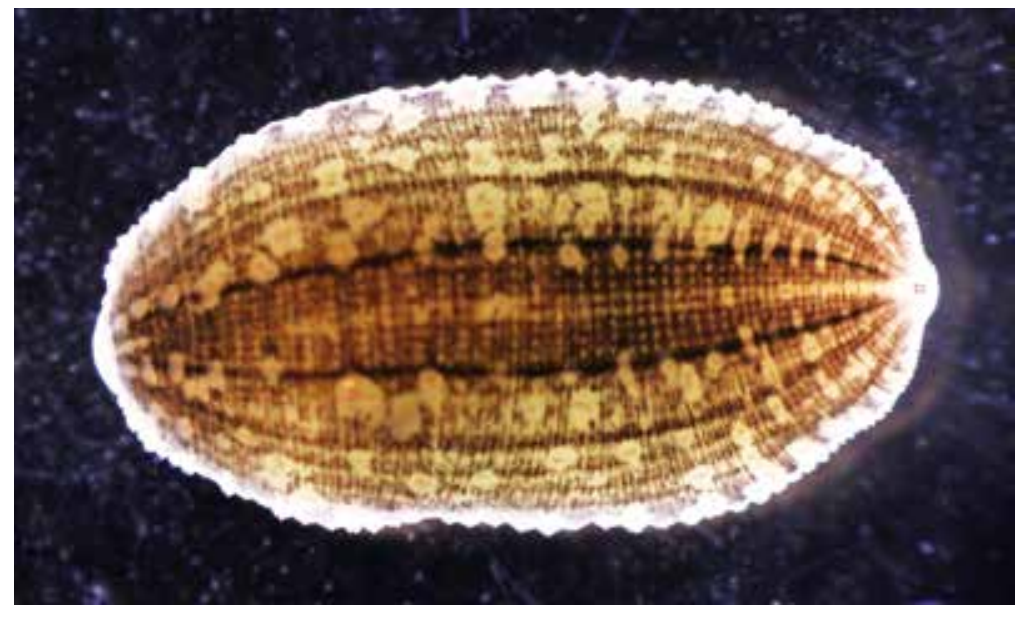

Obr. 18. Pijavka chobotnatka plochá Glossiphonia complanata

Fig. 18. Leech Glossiphonia complanata

Informace o oživení řeky Dyje jsou k nalezení v komplexní studii, která se zabývala jakostí vod v řece Dyji včetně hodnocení biologického. Pozornost byla věnována biosestonu a makrozoobentosu, ze kterých byla stanovována saprobita, tedy hodnocena míra znečištění rozložitelnými organickými látkami [48]. Jedná se o zprávu Výzkumného ústavu vodohospodářského, zachycující stav v letech 1951-1952 a u části analýz též v roce 1954. Z deseti kontrolních profilů se oblasti VD NM týkají Drnholce a Dolních Věstonic.

Poměrně podrobně sledovanou skupinou byly jepice (Ephemeroptera). Skalníková [49] zpracovávala materiál ze sbírek tehdejšího Zoologického ústavu Masarykovy univerzity, doplněné o údaje ze sbírky dr. Zelinky. K zájmovému území VD NM patřila lokalita Dyje u Dolních Věstonic, luční tůň u soutoku Dyje a Svratky, řeka Jihlava u mostu Ivaň-Mušov, u Mušova a také Dyje v Drnholci. Zelinka [50] se podrobněji zabýval jepicemi dolního toku řeky Jihlavy. Sledoval úsek řeky od tehdejšího soutoku se Svratkou cca do $5 \mathrm{~km}$ proti proudu, tedy v oblasti současné střední nádrže a úseku v okolí obce Ivaň. Koryto řeky bylo již v té době zčásti upravené (uměle vyrovnané a hluboce zaříznuté, jak udává autor), habitatová diverzita však byla zřejmě do značné míry zachována, nebot' se střídaly úseky peřejnaté s vysokou rychlostí proudu a kamenitým dnem a úseky štěrkovité s vodou pomalu tekoucí. Zaznamenáno bylo 26 druhů, poprvé byl zjištěn vzácný druh jepice Brachycercus harrisellus. Stejnou skupinu na rưzných biotopech v oblasti dnešního VD NM a v okolí obce Ivaň studoval

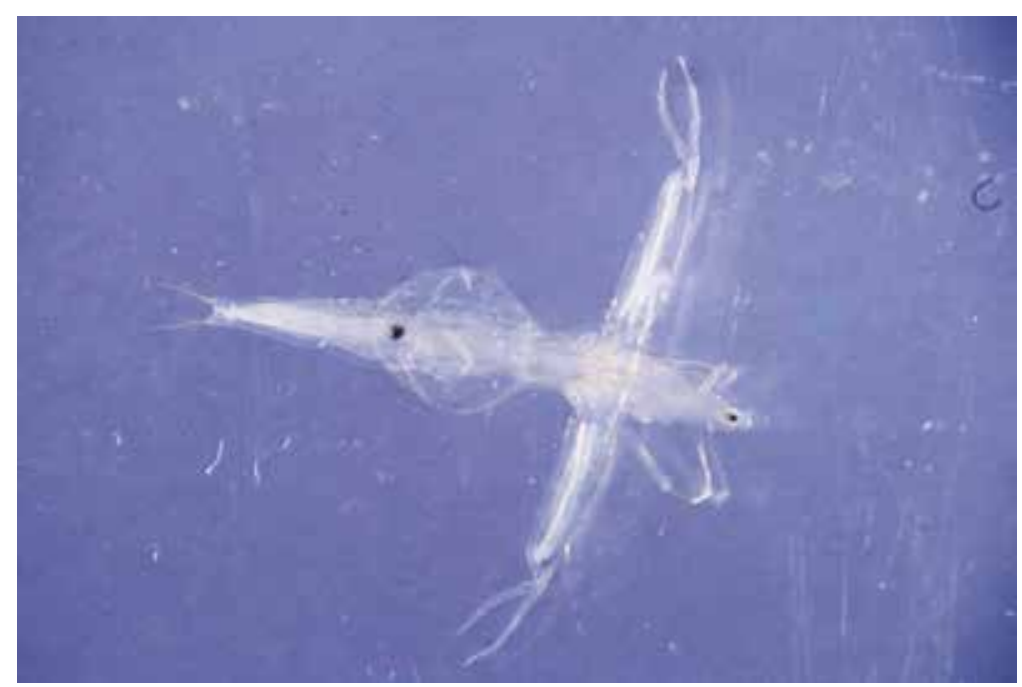

Obr. 19. Dravá perloočka ramenatka velká Leptodora kindtii má téměř průsvitné tělo Fig. 19. Leptodora kindtii is a quite large, nearly transparent predatory water fleas 


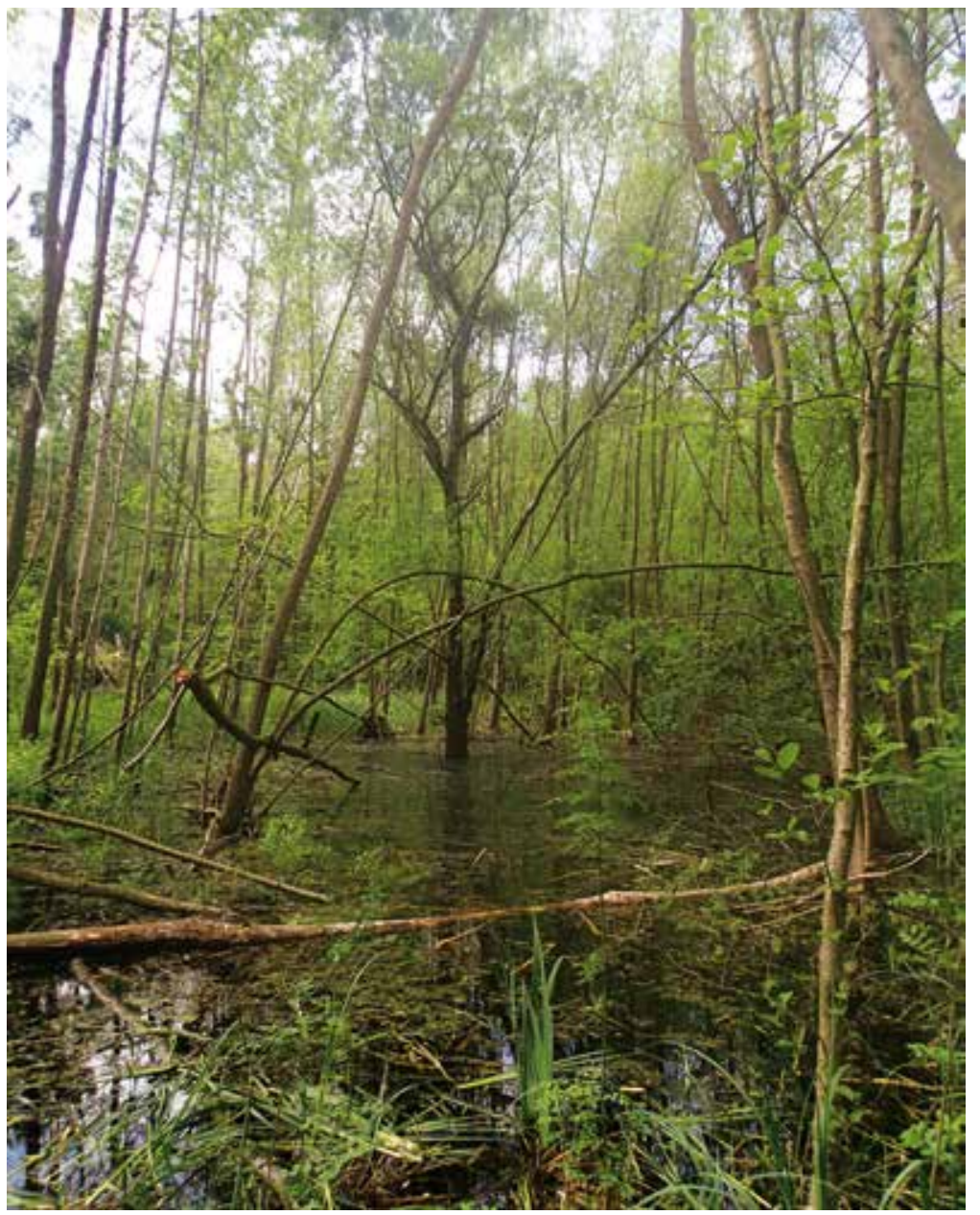

Obr. 20. Periodická tůn̆ v Plačkově lese

Fig. 20. A periodic pool in the floodplain forest Plačkův les

v letech 1963 a 1964 Brabec [51]. Autor zjistil celkem 32 druhů jepic (7 druhů $\vee$ trvalých tůních, 2 druhy v periodických tůňkách a 27 druhů v řekách), což je téměř třetina druhů uváděných $v$ současnosti z celé České republiky. Z lokality na řece Jihlavě uváděl vzácné nálezy včetně dnes již v ČR vyhynulého druhu Isonychia ignota (obr. 21) a doložil tak mimořádnou hodnotu tohoto říčního úseku, který v současnosti náleží do evropsky významné lokality Mušovský luh. Na taxonomické složení této skupiny v řece Jihlavě v uvedeném úseku Ize usuzovat také z poměrů na lokalitě poněkud vzdálenější, ale s obdobným charakterem u obce Cvrčovice, kde Zahrádka [52] uvádí řadu druhů jepic včetně druhů vzácných i takových, které nejsou v ČR od 70. let 20. století nalézány (Ephemerella mesoleuca) - viz obr. 22.

Další významnou skupinou hmyzu, která má larvy žijící v různých vodních biotopech a dospělá stádia jsou terestrická, okřídlená, podobná nenápadným drobným motýlům, jsou chrostíci (Trichoptera). Simanov [53] sledoval v letech 1962-1964 faunu chrostíků na řadě lokalit na jižní Moravě, včetně území VD NM a jeho okolí. Pobliž Mušova sledoval pravidelně stálé i periodické tůně a také řeku Jihlavu. Zpracoval i materiál dalších sběratelů, celkem determinoval 45 druhů chrostíků v námi sledovaném území. Práce je provedena důkladně, je doprovázena mapkami, fotografiemi a nákresy; je cenným zdrojem informací pro hodnocení stavu taxocenóz chrostíků před výstavbou VD NM. Další informace o výskytech zástupců této skupiny ze sledované oblasti lze najít v práci profesora Obra, shrnující výsledky odlovů chrostíků na světlo v tehdejším Československu [54]. Údaje pocházejí např. ze Strachotína (1976-1979) a také z dalších lokalit v širším okolí VD NM.
Souhrnnou prací o fauně bezobratlých záplavových území na jižní Moravě je studie Adámka a Sukopa, kteří shrnuli výsledky jak svých dřívějších výzkumů, tak nepublikovaných výsledků z diplomových prací jiných autorů [55]. Výsledky člení podle biotopů na řeku, odříznutá říční ramena, nádrže, tůně a zaplavované louky. Práce zahrnuje i informace ze studie Adámkovy, provedené v jarním období v roce 1969 na území budoucích nádrží, a to na trase Brod nad Dyjí-Pasohlávky a Strachotín-Dolní Věstonice. Pozornost věnoval makrozoobentosu zaplavených luk [56]. Mimo běžné druhy zaznamenal druh periodických tůní, listonoha jarního (Lepidurus apus), viz obr. 17, který uvádí jako hojný v blízkosti obce Brod nad Dyjí.

Makrozoobentosu tůní v oblasti budoucí nádrže byly věnovány také některé práce diplomové, popř. rigorózní, vázané na stanici v Mušově. K významnějším patří studie Halouzkovy a Gajdůškovy [57-59].

Výzkumy ovšem pokračovalyi během výstavby nádrží. Napríklad Halouzka [60] sledoval makrozoobentos horní zdrže ve druhém roce po jejím napuštění a také tůně v území střední zdrže. Výsledky [61] jsou pak včleněny do monografie nazvané Biologie nově napuštěné nádrže.

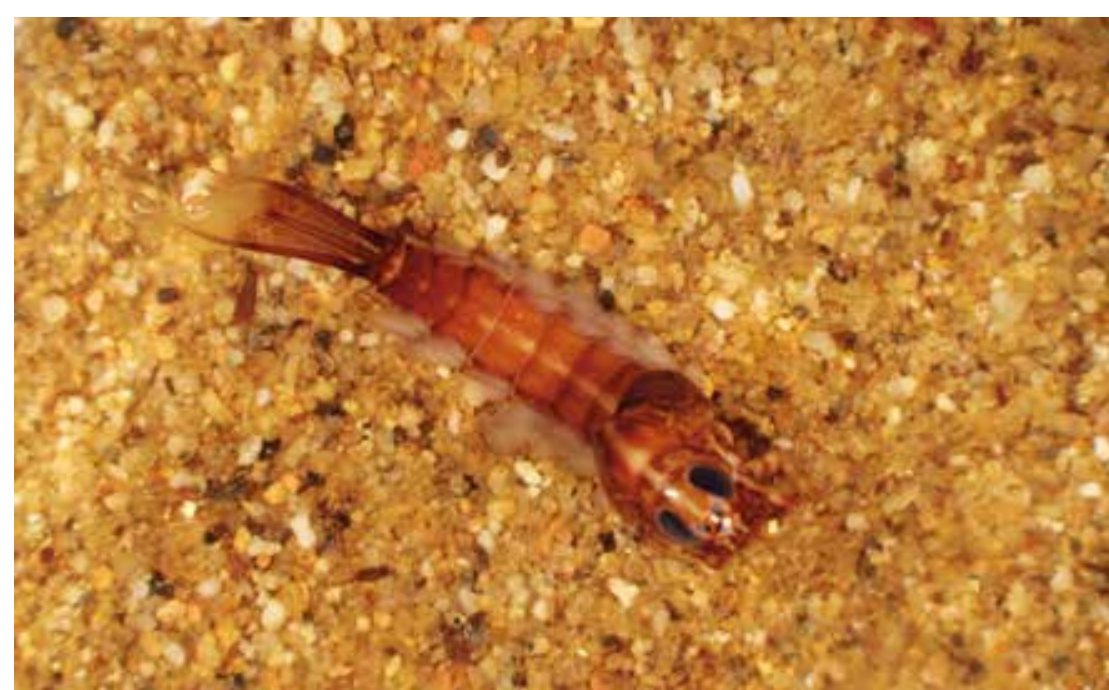

Obr. 21. Jepice Isonychia ignota - druh v České republice vyhynuly

Fig. 21. Mayfly Isonychia ignota became extinct in the Czech Republic

Specifickému prostředí periodických tůní byla věnována pozornost v řadě výše uvedených prací. Přehled historických údajů, včetně osobních sdělení jiných badatelů a $\vee$ menší míre také výsledky vlastních výzkumů $\vee 80$. letech 20. století, shrnul $v$ diplomové práci Kuczman [62]. Jím hodnocená území Vranovice-Pouzdřany, Podivín-Lednice, Pouzdřany-Uherčice, Strachotín-Pavlov zcela nebo zčásti náleží k území sledovanému pro hodnocení VD NM.

$\checkmark$ pozdějším období, tedy po napuštění nádrží, byly již sledovány především samotné nádrže, popř. biotopy řeky Dyje a tůně níže položené, mimo blízké okolí VD NM. Jednou z prací, která studovala řiční biotopy pod hrází dolní zdrže, byla Horsákova studie [61]. Tento autor publikoval seznam 261 taxonů akvatických bezobratlých zjištěných během poměrně podrobného a taxonomicky velmi kvalitně zpracovaného výzkumu, který probíhal na řece Dyji v letech 1998 a 1999. Sledoval pět lokalit pod VD NM, první pod dolní nádrží, poslední se nacházely pod Břeclaví. Hlavním cílem studie bylo vyhodnotit vliv VD NM na ríční biotu, tato analýza pak byla provedena v práci Horsák a kol. [64] se závěrem, že vliv nádrží byl překryt důsledky změn morfologie koryta řeky.

Z recentních prací, které se zabývají sledovanou oblastí, je třeba zmínit studii zabývající se akvatickými měkkýši řeky Dyje a jejích př́toků, zejména se zřetelem na význam těchto toků pro šírení nepůvodních druhů na straně jedné a jejich rolí coby refugií pro druhy ohrožené na straně druhé [65]. Autor sledoval celkem 75 lokalit, z toho značná část náleží k území sledovanému při hodnocení 


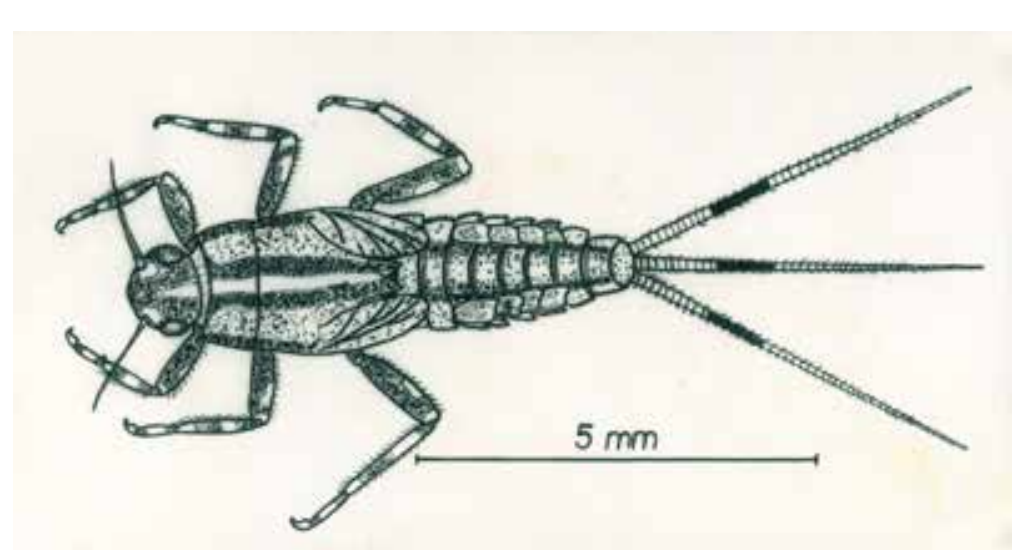

Obr. 22. Larva vymizelé ríční jepice Ephemerella mesoleuca (fotografie: J. Halouzka) Fig. 22. Riverine mayfly Ephemerella mesoleuca disappeared from the South Moravia (photo: J. Halouzka)

VD NM. Dílčí informace o říčním makrozoobentosu jsou uloženy také v datových zdrojích tzv. saprobiologického monitoringu [66]. V současnosti jsou samotné nádrže a říční úseky sledovány především v Rámcovém programu monitoringu v souladu s § 13 vyhlášky č. 98/2011 Sb.

Z obsáhlého souboru dat o nejrůznějších skupinách bezobratlých živočichů jsme pro dokumentaci změn struktury biotopů v hodnocené oblasti vybrali jako stěžejní makrozoobentos, významný zejména pro říční biotopy, a velké lupenonohé korýše - obyvatele periodických tůní. Planktonní korýše jsme hodnotili doplňkově, zejména pro charakterizaci volné vody nádrží VD NM.

Z rešerše poměrně rozsáhlého materiálu bylo dosud zjištěno více než 3000 záznamů o výskytu jednotlivých taxonů vodních bezobratlých. Na nich Ize doložit modelové reakce na důsledky výstavby vodního díla:

A. Druhy, které na území dnešních Novomlýnských nádrží žily, ale s výstavbou nádrží vymizely i z blízkého okolí: Do této skupiny vodních bezobratlých patří zejména druhy větších nízinných řek, tedy biotopů, které byly výstavbou Novomlýnských nádrží dotčeny nejvíce. Druhy jepic Isonychia ignota (obr. 21) a Ephemerella mesoleuca (obr. 22), které na území dnešního VD NM tvořily poslední žijící populace v ČR [51], se zánikem vhodných biotopů na území ČR vyhynuly úplně [67]. Jedná se o citlivé a teplomilné druhy velkých řek, jejichž lokalit ubývá vzhledem k rozsáhlé degradaci tohoto typu biotopu [68]. Ve sledovaném území pravděpodobně došlo ke kombinaci více vlivů: morfologické degradace a fragmentace říční sítě spojené s výstavbou VD NM i předchozími vodohospodářskými zásahy, zhoršení jakosti vody v 70. a 80. letech 20. století a pravděpodobně i v důsledku změn teplotního režimu v řece Jihlavě ve stejném období (synergie jevů, které nastaly $\vee$ souvislosti $s$ výstavbou a provozem soustavy nádrží Dalešice-Mohelno a v průměru chladnějších let).

B. Druhy, které na území dnešních Novomlýnských nádrží žily a s výstavbou nádrží byly vytlačeny do zbytků prírozených biotopů v blízkém okolí: Druhou skupinu organismů tvoří zejména korýši periodických tůní, tedy biotopu, který byl pro sledované území typický - např. žábronožka sněžní (Eubranchipus grubii) a listonoh jarní (Lepidurus apus), viz obr. 17. Tyto druhy jsou uváděny např. v práci Valouška [47] a Kuczmana [62]. Také korýš srostlorep kráčivý (Stygobromus ambulans) se stále ještě vyskytuje např. v periodických lesních tůních Plačkova lesa. Dalším zástupcem této skupiny je jepice nízinných toků Ephoron virgo, viz obr. 4 (historické nálezy [51]), která je na území ČR kriticky ohrožená, a jedna z posledních lokalit $v$ ČR, kde se tento druh recentně vyskytuje, je Jihlava u Ivaně. Ve sledované oblasti se jeví jako nejzávažnější riziko prípadné ohrožení řičního biotopu, který je ojedinělý a pritom zranitelný vazbou na poměrně velké a intenzivně využívané povodí.
C. Druhy, které na území dnešních Novomlýnských nádrží žily a žijí tam i dnes: Další skupinou organismů jsou ty druhy, které nebyly výstavbou VD NM dotčeny. Jedná se zejména o tzv. ubikvistní druhy (generalisté), tedy druhy s širokou ekologickou valencí schopné úspěšně přeživat v široké škále vodních biotopů, např. o hojně rozšířenou jepici dvoukrí́dlou (Cloeon dipterum) nebo o motýlici lesklou (Calopteryx splendens). Výskyt těchto druhů, zejména pokud by se počet lokalit zvyšoval, však může indikovat spíše horší stav v krajině, kdy jsou citlivé druhy nahrazovány druhy odolnými. Do této kategorie patří také mlž velevrub maliřský (Unio pictorum), viz obr. 9, a škeble rybničná (Anodonta cygnea), viz obr. 8.

D. Druhy, které na území dnešních Novomlýnských nádrží nežily a vyskytly se tam až po výstavbě nádrži: Poslední skupinou organismů jsou ty organismy, pro které výstavbou velké vodní nádrže vznikl nový biotop, který následně osídlily. Modelovým př́kladem může být perloočka ramenatka velká (Leptodora kindtii)viz obr. 19, která je vázána právě na velké vodní nádrže a jezera, a drobný plž písečník novozélandský (Potamopyrgus antipodarum) - viz obr. 23. Výskyt takových druhů, které se $v$ dané krajině dřive vyskytovaly $v$ menší míře nebo vůbec ne, popř. velké zvýšení jejich početnosti $v$ určité oblasti, indikuje závažnou změnu v krajině, v tomto prípadě změnu ve struktuře biotopů.

Dosavadní výzkumy a analýzy potvrzuji fakt, že výstavbou vodního díla Nové Mlýny došlo $v$ hodnocené oblasti ke značné redukci počtu anebo rozlohy původních biotopů - lužního lesa, poříčních a periodických tůní, mokřadů a podmáčených luk a akcentují to, že nejvíce zasaženým akvatickým biotopem ve sledované oblasti (oblast zátopy a její blízké okolí) jsou nížinné řeky, které výstavbou ztratily tři čtvrtiny své původní rozlohy. Rozsah tohoto jevu není při zběžném posuzování prríliš patrný. Podobně málo nápadné jsou změny v biocenózách vodních bezobratlých, mnohem nápadnější jsou napríklad změny ve výskytu ptáků. Bezobratlí živočichové žijící skrytě pod vodní hladinou však při analýzách ukazují na rozsah změn v krajině, včetně změn, které jsou velmi pravděpodobně již nevratné. $V$ krajních prípadech byly zničeny poslední populace vzácných druhů na území ČR a došlo tak k jejich regionálnímu vyhubení. Další kriticky ohrožené druhy ještě prežívají ve zbylých biotopech v blízkém či širším okolí. Cesta $\mathrm{k}$ jejich záchraně vede $v$ dotčené oblasti predevším citlivými vodohospodářskými a zemědělským postupy, včetně budování zelené infrastruktury v krajině - její terestrické i akvatické složky. Vodní dílo Nové Mlýny je tak odstrašujícím př́kladem rozsáhlého technokratického řešení důsledků problémů ve vodním režimu krajiny namísto koncepčního řešení příčin problému $\checkmark$ celém povodí.

\section{ZÁVĚR}

Řeky tekoucí v kaňonech patří k nejvhodnějším místům pro výstavbu přehrad a také na řadě míst jsou již nádrže vybudovány. Výstavbou vodních děl tak zanikla celá řada unikátních oblastí se specifickými podmínkami, které byly z prírodovědného hlediska nesmírně cenné, jak z hlediska terestrických, tak akvatických biotopů. Ve sledovaných oblastech došlo ke značné redukci rozlohy původních biotopů a na ně vázané fauny a flóry. Z výsledků analýz vyplynulo, že nejvíce zasaženým akvatickým biotopem ve sledované oblasti (oblast zátopy a její blízké okolí) jsou nížinné řeky, značně redukovány byly pořiční a periodické tůně, mokřady a podmáčené louky i lužní les. 


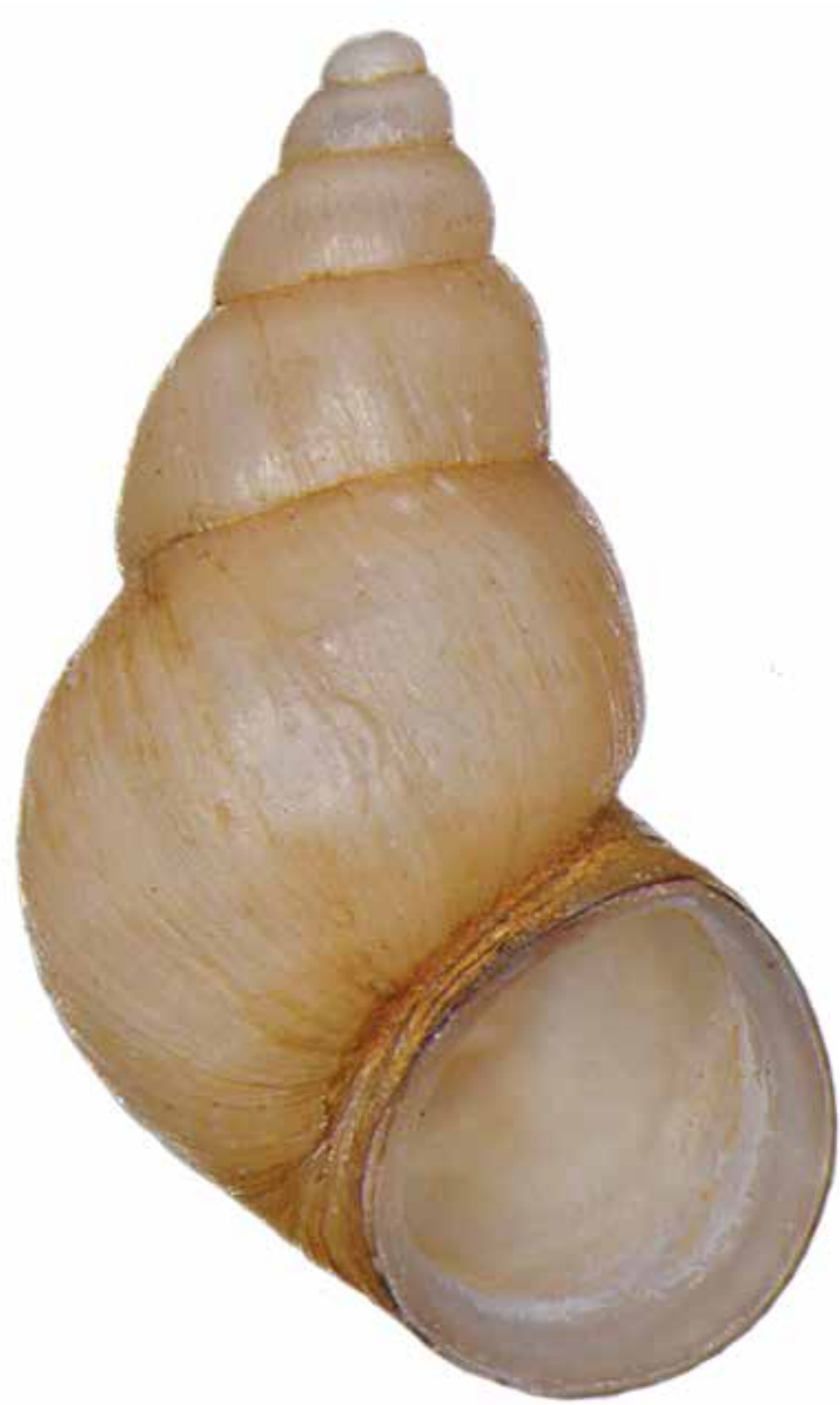

Obr. 23. Invazní plž písečník novozélandský (Potamopyrgus antipodarum) (fotografie: M. Horsák) Fig. 23. The invasive New Zealand mud snail (Potamopyrgus antipodarum) (photo: M. Horsák)

V případě nádrže Vranov došlo k zániku mimořádného typu toku - potamálního úseku reky tekoucí v kaňonu, a to jak na zaplaveném území, tak i v cenném území NP Podyjí. Řeka Svratka je v úseku vzdutí Brněnské přehrady morfologicky degradována, pod nádrží protéká brněnskou aglomerací a její návrat $k$ přirozené diverzitě biotopů $v$ řece i nivě stejně jako diverzitě jejich oživení je velmi ztižen. Výstavba vodního díla Nové Mlýny, která prakticky zlikvidovala cenné území lužních lesů, velmi významně ovlivnila celý krajinný ráz a prírodní podmínky. Významně se změnila struktura vodních biotopů a došlo ke změnám vodního režimu krajiny. Analýzy vodních bezobratlých živočichů ukazuji na velký rozsah velmi pravděpodobně nevratných změn.

$\checkmark$ obecné rovině je třeba velmi pečlivě zvažovat všechny zásahy do krajiny a je třeba vyhýbat se dalším tvrdým technickým opatřením, jako je výstavba nádrží a prríčných přehrážek na tocích vůbec, budování umělých kanálů a převodům vody z povodí do povodí. To vše jen zhoršuje ekologický stav toků a jejich niv, otevírá cestu pro nepůvodní druhy a vede k narušení funkcí - ekosystémových služeb, které ríční systémy mají.

\section{Poděkování}

Článek vznikl za podpory projektu Programu aplikovaného výzkumu a vývoje národní a kulturni identity (NAKI) Ministerstva kultury ČR (DF13P01OVV012).

\section{Literatura}

[1] HRABĚ, V. K poznání fauny príbřežní zóny Kníničské údolní nádrže. Publ. Fac. Sci. Univ. J. E. Purkyně, 1962,433, s. $177-202$

[2] BUNN, S.E. and ARLINGTON, A.H. Basic Principles and Ecological Consequences of Altered Flow Regimes for Aquatic Biodiversity. Environmental Management, 2002, 30, p. 492-507.

[3] KUBÍČEK, F., HELĚ̌IC, J., VOJTÍSKKOVÁ, D., and ZAHRÁDKOVÁ, S. The impact of the Vranov reservoir hydropower station operation on the bottom biota of the Dyje River (Czech Republic). In: Heleśic, J., Kubíček, F. (eds) Hydrobiology of the Dyje River in the National Park Podyjí, Czech Republic. Folia Fac. Sci. Nat. Univ. Masarykianae Brunensis, Biologia, 1999, 102, p. 7-94.

[4] DUŠEK, J. Studie řeky Dyje. Návrh opatření ekologicky únosného hydrologického režimu pod Vranovskou přehradou. Zpráva pro SNP Podyjí, DAPHNE ČR, 2011, 27 s.

[5] ZELINKA, M., KOMENDOVÁ, V., KARTOUS, K., ANTL, J., BOJANOVSKÁ, M., KUBÍČEK, F. a MARVAN, P. Předběžný výzkum jakosti vody přehrad v povodí řeky Moravy. Část II. - přehrady: Vranov, Kníničky, Bystř̌čka, Horní Bečva. Výzkumný ústav vodohospodářský v Praze, laboratoře v Brně, výzkumná zpráva, 1953, 57 s.

[6] HAEMPEL, O. and STUNDL, K. Fischereibiologische Untersuchungen an der Frainer Talsperre. Archiv für Hydrobiologie, 1943, 40, p. 538-554.

[7] HUDCOVÁ, O. Metody lovení planktonu. Diplomová práce, Masarykova universita v Brně, 1949.

[8] MOLíK, K. Výzkum planktonu na Vranovské přehradě. Diplomová práce, Masarykova universita $\checkmark$ Brně, 1949.

[9] VLČKOVÁ, D. Př́spěvek k hydrobiologickému průzkumu Vranovské přehrady. Diplomová práce, Masarykova universita v Brně, 1952.

[10] KUBíČEK, F. K poznání zooplanktonu Vranovské přehrady Spisy PFU v Brně, 1959, 8, 408, s. 419-436. [11] BARTÁKOVÁ, O. Zoobentos Vranovské přehrady podle sběrů prof. Hraběte. Diplomová práce, PřF, UJEP v Brně, nyní Masarykova univerzita, 1971.

[12] HELEŠIC, J., KUBÍČEK, F., and ZAHRÁDKOVÁ, S. The impact of regulated flow and altered temperature on river bed macroinvertebrates. In: Bretschko, G., Helešic, J. (eds): Advances in river bottom ecology. Backhuys Publ., Leiden, 1998, p. 223-241.

[13] LANDA, V. Fauna ČSSR. Jepice - Ephemeroptera. Academia Praha, 1969, 18, 352 s.

[14] LANDA, V. a SOLDÁN, T. Rozšíření rádu Ephemeroptera v ČSSR s ohledem na kvalitu vody. Studie ČSAV, Academia, Praha, 1989, 17, s. 1-172.

[15] HORÁK, P., BABÍKOVÁ, D., BERNARDOVÁ, I., FOREJTNÍKOVÁ, M. a kol. Hodnocení jakosti povrchových vod $\vee$ období 1996-2000. Saprobiologický monitoring SVHB. Závěrečná zpráva. Výzkumný ústav vodohospodářský T. G. Masaryka, pobočka Brno, 2001.

[16] KOKEŠ, J., ZAHRÁDKOVÁ, S., NĚMEJCOVÁ, D., HODOVSKÝ, J., JARKOVSKÝ, J., and SOLDÁN, T. The PERLA system in the Czech Republic: A multivariate approach to assess ecological status of running waters. Hydrobiologia, 2006, 566, p. 343-354.

[17] HELEŠIC, J. and KUBÍČEK, F. Hydrobiology of the Dyje River in the National Park Podyjí, Czech Republic. Folia Fac. Sci. Nat. Univ. Masarykianae Brunensis, Biologia, 199, 102, 138 p.

[18] NYKLOVÁ, E. Ekologický stav Klaperova potoka: hodnocení podle makrozoobentosu. Diplomová práce, PřF, Masarykova univerzita, Brno, 2005.

[19] PAŘIL, P. Vliv extrémních hydrologických situací na strukturu vybraných skupin permanentní a temporární složky bentické fauny v tocích. Dizertační práce, PřF, Masarykova univerzita, Brno, 2011.

[20] ŘEZNí̌KKOVÁ, P. Makrozoobentos Gránického potoka: ekologický stav toku. Diplomová práce, PY̌F, Masarykova univerzita, Brno, 2004

[21] BRABEC, L. Jepice (Ephemeroptera) zátopového území na jižní Moravě v okolí Mušova. Diplomová práce. PřF, UJEP v Brně, dnešní Masarykova univerzita, 1965, 65 s.

[22] KVARDOVÁ, H. Základní funkční schéma a struktura společenstva makrozooplanktonu přirozených a umělých tůní v NP Podyjí. Diplomová práce. PřF, Masarykova univerzita, Brno, 2004.

[23] REITER, A., MERTA, L. a SYCHRA, J. Nové nálezy velkých lupenonožců (Crustacea: Anostraca, Notostraca, Spinicaudata) na Znojemsku. Thayensia (Znojmo), 2014, 11, s. 89-106.

[24] MERTA, L., ZAVADIL, V. a SYCHRA, J. Atlas rozšíření velkých lupenonožců České republiky. Agentura ochrany prírody a krajiny ČR, 2016, $111 \mathrm{~s}$.

[25] FARKAČ, J., KRÁL, D. a ŠKORPÍK, M. (eds.) Červený seznam ohrožených druhů České republiky. Bezobratlí. [List of threatened species in the Czech Republic. Invertebrates.] Agentura ochrany prírody a krajiny ČR, Praha, 2005, 760 s.

[26] BRABEC, K. Vliv údolní nádrže na zoobentos toku pod ní. Diplomová práce, PřF, Masarykova univerzita, Brno, 1994, $71 \mathrm{~s}$. 
[27] SPANDL, H. Zur Kenntnis der Tierwelt vorübergehender Gewässer. ZoologischerAnzeiger, 1923, 56, $1 / 2$, p. 36-41.

[28] SPANDL, H. Die Phyllopodenfauna des mittleren und südlichen Mähren. Verhandlungen der Zoologisch-Botanischen Gesellschaft in Wien, 1926, (74-75), p. 1-37.

[29] ROČEK, J. O čistotu povrchových vod. Hygienické studie na řece Svitavě a Svratce. Spisy Lékařské fakulty Masarykovy univerzity v Brně. ČSR, XI, 1931, 6, s. 1-122.

[30] MUSIL, R. a PROCHÁZKA, V. Kníničská přehrada (výzkum zooplanktonu). Státní práce ze zoologie. Prírodovědecká fakulta MU v Brně, 1949

[31] LOSOS, B. Príspěvek k hydrobiologickému průzkumu Kníničské přehrady. Práce Moravskoslezské akad. věd prír., 1952, roč. 24, 17, s. 379-425.

[32] ZELINKA, M. a kol. Výzkum jakosti vod vody přehrad v povodí řeky Moravy, část V. Zpráva Výzkumného ústavu vodohospodářského, Brno, 1954.

[33] ZELINKA, M., SKALNíKOVÁ, J. (1959): K poznání jepic (Ephemeroptera) z povodí řeky Moravy. Spisy prír. fak. Univ. Brno, 401: 89-96.

[34] HRABĚ, S. (1953): První nález mechovky Pectinatella magnifica Leidy na Moravě. Scripta medica 25. Citováno z HRABĚ, V. (1960): K poznání fauny litorální zóny Kníničské údolní nádrže. Diplomová práce, Masarykova univerzita, $84 \mathrm{~s}$.

[35] HRABĚ, V. K poznání fauny přibřežní zóny Kníničské údolní nádrže. Publ. Fac. Sci. Univ. J. E. Purkyně, 1962,433, s. $177-202$.

[36] ŠRÁMEK-HUŠEK, R. Perloočky a buchanky našich přehrad. I Věstník čsl. zoologické společnosti., 1957, 21,2 , s. 112-125.

[37] ŠRÁMEK-HUŠEK, R. Podzimní plankton několika československých přehrad. Zoologickélisty, 1960, 9,1, s. 59-70.

[38] KUBíČEK, F. K poznání hydrobiologických poměrů Kníničské přehrady, zejména zooplanktonu. Kandidátská dizertační práce, UJEP $\vee$ Brně, 1961, 94 s.

[39] JIRSOVÁ, P. Bentická fauna řičky Veverky. Diplomová práce, Masarykova univerzita, Brno, 1998, $68 \mathrm{~s}$.

[40] SPANDL, H. Die Entomostrakenfauna der Schwarza nächst Brünn. Verhandlungen des naturforschenden Vereines in Brünn, Band LVIII, 1923, p. 97-102

[41] SPANDL, H. Die Tierwelt vorübergehender Gewässer der Umgebung Brünns. Osmá výroční zpráva komise na prír. výzkum Moravy a Slezska v Brně za léta 1914-24, 1925, p. 41-44.

[42] NËMEJCOVÁ, D., ZAHRÁDKOVÁ, S. a POLÁŠEK, M. Nenápadný svět vodních bezobratlých - obraz vývoje krajiny. Sborník XXXII. Mikulovského sympozia, Brno 2015, 2015, s. 407-415.

[43] SUKOP, I. Influence of water works at Nové Mlýny on macrozoobenthos of the Dyje River in the vicinity of Biosphere Reserve Pálava (southern Moravia). Ekológia, (Bratislava), 1990, 9, s. 73-86.

[44] BERAN, L., HORSÁK, M. Aquatic molluscs (Gastropoda, Bivalvia) of the Dolnomoravský úval lowland, Czech Republic. Acta Soc. Zool. Bohem., 1998, 62, p. 7-23.

[45] OPRAVILOVÁ, V., VAŇHARA, J. a SUKOP, I. (eds) (1999): Aquatic Invertebrates of the Pálava Biosphere Reserve of UNESCO. Folia Fac. Sci. Nat. Univ. Masaryk. Brun., Biol., roč. 101: 1-279.

[46] KUBÍČEK, F. Daphnia atkinsoni BAIRD a několik vzácných buchanek z jarních vod jižní Moravy. Sborník klubu prírodovědců, Brno, 1951, 29, s. 221-231.

[47] VALOUŠEK, B. Periodická sněžní tůň jako biotop. Acta Acad. Sci. Nat. Moravo-Silesiacae, 1951, roč. 23,20, s. $411-434$

[48] MAZEL, L., SOBOTKOVÁ, E., VALENTOVÁ, Z., ZELINKA, M., a kol. Výzkum jakosti vody v povodí řeky Moravy. Řeka Dyje. Výzkumný ústav vodohospodářský v Praze, laboratoře v Brně, výzkumná zpráva, $1954,75 \mathrm{~s}$

[49] SKALNÍKOVÁ, J. Jepice Moravy. Diplomová práce. Brno: Masarykova univerzita, 1958, 89 s.

[50] ZELINKA, M. Jepice dolního toku řeky Jihlavky. Sbor. Klubu prírodov., Brno, 1960, 32, s. 81-85.

[51] BRABEC, L. Jepice (Ephemeroptera) zátopového území na jižní Moravě v okolí Mušova. Diplomová práce. UJEP $\vee$ Brně, dnešní Masarykova univerzita, 1965, 65 s.

[52] ZAHRÁDKA, J. Produkční biologie dvou druhů jepic - Potamanthus luteus a Ephoron virgo. Diplomová práce. UJEP $\vee$ Brně, dnešní Masarykova univerzita, 1976, 68 s.

[53] SIMANOV, L. K poznání chrostíků (Trichoptera) jižní Moravy. Diplomová práce. UJEP v Brně, dnešní Masarykova univerzita, 1965, $90 \mathrm{~s}$.

[54] OBR, S. Chrostíci (Trichoptera) ulovení na světlo v Československu. Práce z oboru botaniky a zoologie (1980-1983). Klub prír., Brno, 1984, s. 77-92.

[55] ADÁMEK, Z. and SUKOP, I. Invertebrate communities of former southern Moravian floodplains (Czechoslovakia) and impacts of regulation. Regul. Rivers Res. Mgmt, 1992, vol. 7, p. 181-192.

[56] ADÁMEK, Z. Bentos zaplavovaných jihomoravských luk. Památky a príroda, 1976, 4, s. 251-253.

[57] GAJDU゚ŠEK, J. Zoobenthos poříčních tůní u Mušova. Diplomová práce. UJEP v Brně, dnešní Masarykova univerzita, 1967, $59 \mathrm{~s}$.

[58] GAJDU゚ŠEK, J. Zoobentos poříčních tůní u Mušova. Rigorózní práce. UJEP $\vee$ Brně, dnešní Masarykova univerzita, 1969, $122 \mathrm{~s}$.
[59] HALOUZKA J. Bentos tůní oblasti přehrady Nové Mlýny. Diplomová práce. UJEP v Brně, dnešni Masarykova univerzita, 1977, 80 s.

[60] HALOUZKA, J. Makrozoobentos mušovské přehradní nádrže druhým rokem po jejím napuštění a přehled hydrobiologických výzkumů s důrazem na zoobentos v oblasti Vodního díla Nové Mlýny. Rigorózní práce. UJEP v Brně, dnešní Masarykova univerzita, 1980, 96 s.

[61] SUKOP, I. a HALOUZKA, J. Vývoj zoobentosu Horní zdrže v letech 1979-1980. In: Heteša, J. a Marvan P. (eds) Biologie nově napuštěné nádrže. Praha, Studie ČSAV, 1984, roč. 3, s. 114-119.

[62] KUCZMAN, O. Periodické tůně jižní Moravy, minulost a současný stav některých lokalit. Diplomová práce. UJEP v Brně, dnešní Masarykova univerzita, 1984, 60 s.

[63] HORSÁK, M. Contribution to our knowledge of macroinvertebrate fauna of the Dyje River downstream of the Nové Mlýny reservoirs (Czech Republic). Scripta Fac. Sci. Nat. Univ. Masaryk. Brun. Suppl., Biology, 2001, 27, p. 41-62.

[64] HORSÁK, M., BOJKOVÁ, J., ZAHRÁDKOVÁ, S., OMESOVÁ, M., and HELEŠIC, J. Impact of reservoirs and channelization on lowland river macroinvertebrates: A case study from Central Europe. Limnologica, 2009, vol. 39, 2, p. 140-151.

[65] BERAN, L. Freshwater molluscs of the Dyje (Thaya) river and its tributaries - the role of these water bodies in expansion of alien species and as a refugium for endangerd gastropods and bivalves. Folia Malacozoologica, 2013, 3, p. 143-160.

[66] HORÁK, P., BABÍKOVÁ, D., BERNARDOVÁ, I. a kol. Hodnocení jakosti povrchových vod v obdob 1996-2000. Saprobiologický monitoring SVHB. Výzkumná zpráva, Výzkumný ústav vodohospodářský T. G. Masaryka, Brno, 2001.

[67] ZAHRÁDKOVÁ, S., SOLDÁN, T., BOJKOVÁ, J., HELEŠIC, J., JANOVSKÁ, H., and SROKA, P. Distribution and biology of mayflies (Ephemeroptera) of the Czech Republic: present status and perspectives. Aquatic Insects, 2009, vol. 31(Suppl. 1), p. 629-652.

[68] BOJKOVÁ, J., KOMPRDOVÁ, K., SOLDÁN, T., and ZAHRÁDKOVÁ, S. Species loss of stoneflies (Plecoptera) in the Czech Republic during the $20^{\text {th }}$ century. Freshwater Biology, 2012, 57, p. 2550-2567.

\section{Autoři}

RNDr. Denisa Němejcová

$凶$ denisa.nemejcova@vuv.cz

doc. RNDr. Světlana Zahrádková, Ph.D.

$凶$ svetlana.zahradkova@vuv.cz

\section{Mgr. Marek Polášek}

凶marek.polasek@vuv.cz

Výzkumný ústav vodohospodářský T. G. Masaryka, v. v. i.

Příspěvek prošel lektorským řízením. 


\section{DAMS AND AQUATIC INVERTEBRATES}

\section{NEMEJCOVA, D.; ZAHRADKOVA, S.; POLASEK, M.}

TGM Water Research Institute, p. r. i.

Keywords: benthic macroinvertebrates - South Moravia - water reservoirs - river channelization - water management - natural heritage

The construction of water dams fundamentally changes nature and landscape not only in the flooded areas but also out of them, including all structures and links and leading to habitat loss. Three characteristically different South Moravian water reservoirs - the Vranov Dam, the Brno Dam and system of water reservoirs of Nové Mlýny have been studied in the project "Submerged cultural and natural heritage of South Moravia" (DF13P01OVV012) supported by the Ministry of Culture of the Czech Republic. There were specific aquatic habitats linked to the water regime of the landscape in the areas beneath the water of present-day reservoirs. Those have disappeared on the submerged areas however some types are still present nowadays in the near or wider area. Logically, changes in the habitats resulted in changes of aquatic biocenoses.

The objective of the study was to document environmental impact of water dam constructions and reservoirs on different types of aquatic habitats and benthic macroinvertebrate species. The result is an overview of strategies and model responses of benthic macroinvertebrate to such environmental change.

The analysis has shown that the most impacted type of water habitat is a lowland river biotopes and fauna specially bound to the lowland rivers. The species of Ephemerella mesoleuca and Isonychia ignota, which had the last living population in the Czech Republic in today's system of water reservoirs of Nové Mlýny, became extinct altogether with suitable biotopes loss in the Czech Republic. Mayfly Ephoron virgo, a critically endangered river species, inhabits one of the last areas in the Czech Republic in the study areas. Periodic pools were found as a heavily impacted type of water habitat, fauna inhabits vernal periodic pools, mainly large branchiopods, is endangered. 